\title{
Tree height integrated into pantropical forest biomass estimates
}

T. R. Feldpausch ${ }^{1}$, J. Lloyd ${ }^{1,2}$, S. L. Lewis ${ }^{1,3}$, R. J. W. Brienen ${ }^{1}$, M. Gloor ${ }^{1}$, A. Monteagudo Mendoza ${ }^{4}$, G. Lopez-Gonzalez ${ }^{1}$, L. Banin ${ }^{1,5}$, K. Abu Salim ${ }^{6}$, K. Affum-Baffoe ${ }^{7}$, M. Alexiades ${ }^{8}$, S. Almeida ${ }^{9, \dagger}$, I. Amaral ${ }^{10}$, A. Andrade ${ }^{10}$, L. E. O. C. Aragão ${ }^{11}$, A. Araujo Murakami ${ }^{12}$, E. J. M. M. Arets ${ }^{13}$, L. Arroyo $^{12}$, G. A. Aymard C. ${ }^{14}$, T. R. Baker ${ }^{1}$, O. S. Bánki ${ }^{15}$, N. J. Berry ${ }^{16}$, N. Cardozo $^{17}$, J. Chave ${ }^{18}$, J. A. Comiskey ${ }^{19}$, E. Alvarez ${ }^{20}$, A. de Oliveira $^{10}$,

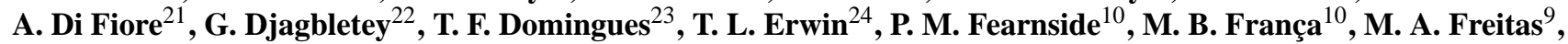
N. Higuchi ${ }^{10}$, E. Honorio C. ${ }^{1}$, Y. Iida $^{25}$, E. Jiménez ${ }^{26}$, A. R. Kassim ${ }^{27}$, T. J. Killeen ${ }^{28}$, W. F. Laurance ${ }^{29}$, J. C. Lovett $^{30}$,

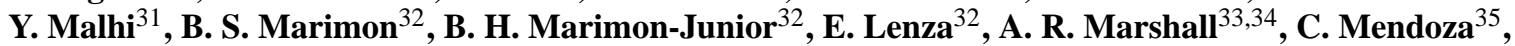

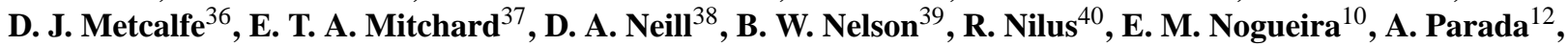
K. S.-H. Peh ${ }^{41}$, A. Pena Cruz ${ }^{42}$, M. C. Peñuela ${ }^{26}$, N. C. A. Pitman ${ }^{43}$, A. Prieto ${ }^{44}$, C. A. Quesada ${ }^{10}$, F. Ramírez ${ }^{17}$, H. Ramírez-Angulo ${ }^{45}$, J. M. Reitsma ${ }^{46}$, A. Rudas $^{47}$, G. Saiz ${ }^{48}$, R. P. Salomão ${ }^{9}$, M. Schwarz ${ }^{1}$, N. Silva ${ }^{49}$, J. E. Silva-Espejo ${ }^{50}$, M. Silveira ${ }^{51}$, B. Sonké ${ }^{52}$, J. Stropp ${ }^{53}$, H. E. Taedoumg ${ }^{52}$, S. Tan ${ }^{54}$, H. ter Steege ${ }^{55}$, J. Terborgh $^{43}$, M. Torello-Raventos ${ }^{2}$, G. M. F. van der Heijden ${ }^{56,57}$, R. Vásquez ${ }^{42}$, E. Vilanova ${ }^{58}$, V. A. Vos ${ }^{59,60}$, L. White ${ }^{61,62,63}$, S. Willcock ${ }^{1}$, H. Woell ${ }^{64}$, and O. L. Phillips ${ }^{1}$

${ }^{1}$ School of Geography, University of Leeds, Leeds, LS2 9JT, UK

${ }^{2}$ School of Earth and Environmental Science, James Cook University, Cairns, Qld 4870, Australia

${ }^{3}$ Department of Geography, University College London, UK

${ }^{4}$ RAINFOR/Jardín Botánico de Missouri, Peru

${ }^{5}$ School of Environmental Sciences, University of Ulster, Cromore Road, Coleraine, BT52 1SA, UK

${ }^{6}$ Biology Programme, Faculty of Science, Universiti Brunei Darussalam, Tungku Link Road BE1410, Brunei Darussalam

${ }^{7}$ Resource Management Support Centre, Forestry Commission of Ghana, P.O. Box 1457, Kumasi, Ghana

${ }^{8}$ New York Botanical Garden, New York City, New York 10458, USA

${ }^{9}$ Museu Paraense Emilio Goeldi, Av. Magalhães Barata, 376, São Braz, 66040-170, Belém, PA, Brazil

${ }^{10}$ National Institute for Research in Amazonia (INPA), C.P. 478, Manaus, Amazonas, 69011-970, Brazil

${ }^{11}$ Geography, College of Life and Environmental Sciences, University of Exeter, Rennes Drive, Exeter, EX4 4RJ, UK

${ }^{12}$ Museo de Historia Natural Noel Kempff Mercado, Universidad Autonoma Gabriel Rene Moreno, Casilla 2489,

Av. Irala 565, Santa Cruz, Bolivia

${ }^{13}$ Centre for Ecosystem Studies, Alterra, Wageningen University and Research Centre, P.O. Box 47,

6700 AA Wageningen, The Netherlands

${ }^{14}$ UNELLEZ-Guanare, Programa de Ciencias del Agro y el Mar, Herbario Universitario (PORT), Mesa de Cavacas,

Estado Portuguesa 3350, Venezuela

${ }^{15}$ IBED, University of Amsterdam, POSTBUS 94248, 1090 GE Amsterdam, The Netherlands

${ }^{16}$ School of GeoSciences, University of Edinburgh, Edinburgh, EH93JN, UK

${ }^{17}$ Universidad Nacional de la Amazonía Peruana, Iquitos, Loreto, Perú

${ }^{18}$ Université Paul Sabatier, Laboratoire EDB, bâtiment 4R3, 31062 Toulouse, France

${ }^{19}$ Mid-Atlantic Network, Inventory and Monitoring Program, National Park Service, 120 Chatham Lane,

Fredericksburg, VA 22405, USA

${ }^{20}$ Jardin Botanico de Medellin, Colombia

${ }^{21}$ Department of Anthropology, University of Texas at Austin, 1 University Station, SAC 5.150 Mailcode C3200,

Austin, TX 78712, USA

${ }^{22}$ Ecosystem and Climate Change Division (ESCCD) Forestry Research Institute of Ghana (FORIG), U.P. Box 63,

KNUST-Kumasi, Ghana

${ }^{23}$ Instituto de Astronomia, Geofísica e Ciências Atmosféricas, Universidade de São Paulo, 05508-090, Brazil

${ }^{24}$ Department of Entomology, Smithsonian Institution, P.O. Box 37012, MRC 187, Washington, DC 20013-7012, USA

${ }^{25}$ Graduate School of Environmental Science, Hokkaido University, Sapporo, 060-0810, Japan 
${ }^{26}$ Universidad Nacional de Colombia, Kilómetro 2 Via Tarapacá, Leticia, Amazonas, Colombia

${ }^{27}$ Forest Research Institute Malaysia (FRIM), 52109 Kepong, Selangor Darul Ehsan, Malaysia

${ }^{28}$ Conservation International, 2011 Crystal Drive, Suite 500, Arlington, VA 22202, USA

${ }^{29}$ Centre for Tropical Environmental and Sustainability Science (TESS) and School of Marine and Tropical Biology, James Cook University, Cairns, Queensland 4878, Australia

${ }^{30}$ CSTM, University of Twente, P.O. Box 217, 7500 AE Enschede, The Netherlands

${ }^{31}$ Environmental Change Institute, School of Geography and the Environment, University of Oxford, UK

${ }^{32}$ Universidade do Estado de Mato Grosso, Campus de Nova Xavantina, Caixa Postal 08, 78.690-000,

Nova Xavantina, MT, Brazil

${ }^{33}$ CIRCLE, Environment Department, University of York, York, UK

${ }^{34}$ Flamingo Land Ltd., Kirby Misperton, YO17 6UX, UK

${ }^{35}$ FOMABO (Manejo Forestal en las Tierras Tropicales de Bolivia), Sacta, Bolivia

${ }^{36}$ CSIRO Ecosystem Sciences, Tropical forest Research Centre, P.O. Box 780, Atherton, QLD 4883, Australia

${ }^{37}$ School of GeoSciences, University of Edinburgh, Drummond St, Edinburgh, EH8 9XP, UK

${ }^{38}$ Universidad Estatal Amazónica, Facultad de Ingeniería Ambiental, Paso lateral km 2 1/2 via Napo, Puyo, Pastaza, Ecuador

${ }^{39}$ Environmental Dynamics Department, National Institute for Research in Amazonia (INPA), C.P. 478, Manaus, Amazonas, CEP 69011-970, Brazil

${ }^{40}$ Sabah Forestry Department, Forest Research Centre, Sandakan, 90715, Malaysia

${ }^{41}$ Department of Zoology, University of Cambridge, Downing Street, CB2 3EJ, UK

${ }^{42}$ Jardín Botánico de Missouri, Oxapampa, Pasco, Peru

${ }^{43}$ Center for Tropical Conservation, Duke University, Box 90381, Durham, NC 27708, USA

${ }^{44}$ Instituto de Ciencias Naturales, Universidad Nacional de Colombia

${ }^{45}$ Universidad de Los Andes, Facultad de Ciencias Forestales y Ambientales, Mérida, Venezuela

${ }^{46}$ Bureau Waardenburg bv, P.O. Box 365, 4100 AJ Culemborg, The Netherlands

${ }^{47}$ Instituto de Ciencias Naturales, Universidad Nacional de Colombia, Colombia

${ }^{48}$ Karlsruhe Institute of Technology, Garmisch-Partenkirchen, Germany

${ }^{49}$ Universidade Federal Rural da Amazônia (UFRA), Brazil

${ }^{50}$ Universidad Nacional San Antonio Abad del Cusco, Av. de la Cultura No. 733. Cusco, Peru

${ }^{51}$ Universidade Federal do Acre, Rio Branco AC 69910-900, Brazil

${ }^{52}$ Department of Biology, University of Yaoundé I, P.O. Box 047, Yaoundé, Cameroon

${ }^{53}$ Institute for Environment and Sustainability, European Commission, DG Joint Research Centre, Via Enrico Fermi 274 , 21010 Ispra, Italy

${ }^{54}$ Sarawak Forestry Corporation, Kuching, Sarawak, Malaysia

${ }^{55}$ Naturalis Biodiversity Center, P.O. Box, 2300 RA, Leiden, The Netherlands

${ }^{56}$ Department of Biological Sciences, University of Wisconsin-Milwaukee, Milwaukee, Wisconsin, P.O. Box 413, 53201, USA

${ }^{57}$ Smithsonian Tropical Research Institute, Apartado 2072, Balboa, Republic of Panama

${ }^{58}$ Instituto de Investigaciones para el Desarrollo Forestal (INDEFOR), Universidad de Los Andes, Mérida, Venezuela

${ }^{59}$ Programa Manejo de Bosques de la Amazonía Boliviana (PROMAB), Casilla 107, Riberalta, Beni, Bolivia

${ }^{60}$ Universidad Autónoma del Beni, Campus Universitario, Av. Ejército Nacional, final, Riberalta, Beni, Bolivia

${ }^{61}$ Agence National des Parcs Nationaux, Libreville, Gabon

${ }^{62}$ Institut de Recherche en Ecologie Tropicale (CENAREST), Gabon

${ }^{63}$ School of Natural Sciences, University of Stirling, UK

${ }^{64}$ Sommersbergseestr. 291, 8990 Bad Aussee, Austria

$\dagger$ deceased

Correspondence to: T. R. Feldpausch (t.r.feldpausch@leeds.ac.uk)

Received: 20 February 2012 - Published in Biogeosciences Discuss.: 8 March 2012

Revised: 13 July 2012 - Accepted: 23 July 2012 - Published: 27 August 2012 
Abstract. Aboveground tropical tree biomass and carbon storage estimates commonly ignore tree height $(H)$. We estimate the effect of incorporating $H$ on tropics-wide forest biomass estimates in 327 plots across four continents using $42656 H$ and diameter measurements and harvested trees from 20 sites to answer the following questions:

1. What is the best $H$-model form and geographic unit to include in biomass models to minimise site-level uncertainty in estimates of destructive biomass?

2. To what extent does including $H$ estimates derived in (1) reduce uncertainty in biomass estimates across all 327 plots?

3. What effect does accounting for $H$ have on plot- and continental-scale forest biomass estimates?

The mean relative error in biomass estimates of destructively harvested trees when including $H$ (mean 0.06), was half that when excluding $H$ (mean 0.13). Power- and Weibull- $H$ models provided the greatest reduction in uncertainty, with regional Weibull- $H$ models preferred because they reduce uncertainty in smaller-diameter classes $(\leq 40 \mathrm{~cm} D)$ that store about one-third of biomass per hectare in most forests. Propagating the relationships from destructively harvested tree biomass to each of the 327 plots from across the tropics shows that including $H$ reduces errors from $41.8 \mathrm{Mg} \mathrm{ha}^{-1}$ (range 6.6 to 112.4 ) to $8.0 \mathrm{Mg} \mathrm{ha}^{-1}$ ( -2.5 to 23.0 ). For all plots, aboveground live biomass was $-52.2 \mathrm{Mg} \mathrm{ha}^{-1}(-82.0$ to -20.3 bootstrapped $95 \% \mathrm{CI}$ ), or $13 \%$, lower when including $H$ estimates, with the greatest relative reductions in estimated biomass in forests of the Brazilian Shield, east Africa, and Australia, and relatively little change in the Guiana Shield, central Africa and southeast Asia. Appreciably different stand structure was observed among regions across the tropical continents, with some storing significantly more biomass in small diameter stems, which affects selection of the best height models to reduce uncertainty and biomass reductions due to $H$. After accounting for variation in $H$, total biomass per hectare is greatest in Australia, the Guiana Shield, Asia, central and east Africa, and lowest in eastcentral Amazonia, W. Africa, W. Amazonia, and the Brazilian Shield (descending order). Thus, if tropical forests span 1668 million $\mathrm{km}^{2}$ and store $285 \mathrm{Pg} \mathrm{C}$ (estimate including $H$ ), then applying our regional relationships implies that carbon storage is overestimated by $35 \mathrm{Pg} \mathrm{C}$ (31-39 bootstrapped $95 \% \mathrm{CI}$ ) if $H$ is ignored, assuming that the sampled plots are an unbiased statistical representation of all tropical forest in terms of biomass and height factors. Our results show that tree $H$ is an important allometric factor that needs to be included in future forest biomass estimates to reduce error in estimates of tropical carbon stocks and emissions due to deforestation.

\section{Introduction}

Accurate estimates of tropical tree biomass are essential to determine geographic patterns in carbon stocks, the magnitudes of fluxes due to land-use change, and to quantify avoided carbon emissions via mechanisms such as REDD+ (Reducing Emissions from Deforestation and forest Degradation). Global estimates of tree carbon in tropical forests vary between 40 to $50 \%$ of the total carbon in terrestrial vegetation (Watson et al., 2000; Kindermann et al., 2008), indicating considerable uncertainty. Such uncertainty is the consequence of linking individual tree measurements to largescale patterns of carbon distribution, as well as the definition as to what constitutes "forest".

The estimation of tree-, plot-, regional-, or global-level mass of tropical trees requires first harvesting and weighing trees (Fittkau and Klinge, 1973), and subsequently estimating biomass on a larger population by measuring tree stem diameter $(D)$ and converting $D$ to biomass based on allometric equations developed using the destructive harvest data (Brown et al., 1989; Overman et al., 1994; Ogawa et al., 1965). Biomass can also be estimated using radar and from light detection and ranging (LiDAR) remote sensingbased methods (e.g., Drake et al., 2002; Mitchard et al., 2011; Morel et al., 2011; Saatchi et al., 2011). Calibration of remotely-sensed biomass requires ground-based biomass estimates derived from stem diameter measurements and allometric equations (either calibrated "on-site" or from the literature to "ground-truth" data) (e.g., Lucas et al., 2002; Mitchard et al., 2009). Both ground- and space-borne biomass estimates have uncertainty, and scaling from plots to regions introduces additional uncertainty. For example, carbon stock estimates for Amazonia based on spatial interpolations of direct measurements, relationships to climatic variables, and remote sensing data have an uncertainty of $\pm 20 \%$ (Saatchi et al., 2007; Houghton, 2010). It is therefore necessary to generate accurate allometric models that reduce uncertainty in tree and plot-level estimates.

The most widely used allometric equation for tropical forest biomass ground-based estimates and validation of satellite-based estimates is based on $\sim 1300$ harvested and weighed moist forest trees (Chave et al., 2005; Chambers et al., 2001), and include no destructive biomass samples from Africa. The small sample size and geographical limits of this dataset are due to the tremendous efforts required to work in remote forests dissecting and determining mass of trees, some of which may weigh over $20 \mathrm{Mg}$. Such a lack of data for calibration may bias estimates of carbon stocks in tropical forests (Houghton et al., 2000; Malhi et al., 2004). One major uncertainty in carbon stock estimates is related to architectural differences in tropical trees. For example, across plots, regions and continents there is significant and systematic variation in tropical forest tree height $(H)$ for a given diameter (Feldpausch et al., 2011; Banin et al., 2012). This applies both to multispecies equations and to those restricted 
to individual species (Nogueira et al., 2008b). Hence, accounting for differences in $H: D$ allometry may reduce uncertainty associated with tropical forest biomass estimates from plot to pantropical scales.

Improving the accuracy of such estimates is important as almost all tropical forest regions of the world are currently undergoing major changes which alter biomass and carbon stocks. For example, it is now apparent that many remaining intact tropical forests are not at carbon equilibrium, but rather are accumulating biomass (Lewis et al., 2009; Phillips et al., 1998). An accurate quantification of this apparent pantropical sink hinges on, amongst other factors, unbiased biomass estimates for individual trees. Similarly, quantifying changes in global carbon stocks and emissions where much of the active deforestation occurs (e.g., arc of deforestation in Brazil, INPE, 2009) can be overestimated when ignoring the effect of tree $H$ on biomass estimates, because trees tend to be shorter for a given $D$ in transitional forests where the most active deforestation fronts often occur (Nogueira et al., 2008b). As a result, carbon emissions from tropical deforestation (INPE, 2009) may be biased. More generally, incorporation of $H$ in biomass estimates may help to account for variation in carbon stocks and could represent potential changes in calculated carbon emissions under deforestation (INPE, 2009), selective logging (Pinard and Putz, 1996; Feldpausch et al., 2005), sinks caused by forest regrowth (Uhl and Jordan, 1984; Feldpausch et al., 2004) and carbon valuation under REDD+ (Aragao and Shimabukuro, 2010; Asner et al., 2010; Gibbs et al., 2007).

Along with wood specific gravity $\left(\rho_{\mathrm{W}}\right)$ (Baker et al., 2004b), tree $H$ has already been incorporated into some regional and pantropical forest biomass allometric models (Brown et al., 1989; Chave et al., 2005). Biomass estimation is then based on a four-step process:

1. measure individual tree $D$;

2. estimate $\rho_{\mathrm{W}}$ at the finest taxonomic level available from $\rho_{\mathrm{W}}$ databases (Chave et al., 2009; Fearnside, 1997);

3. measure or estimate $H$ from allometric models based on the relationship between $H$ and $D$ alone (Brown et al., 1989) or with additional forest structure and climate variables to parameterise $H$ estimates (Feldpausch et al., 2011);

4. use these data to calculate biomass for individual trees from allometric equations based on $D, \rho_{\mathrm{W}}$, and $H$.

Despite the early recognition of the importance of $H$ in biomass estimates (Crow, 1978; Ogawa et al., 1965), in practice $H$ has less frequently been accounted for in pantropical biomass estimates due to lack of data. Nevertheless, where data have been available, inclusion of $H$ has been shown to appreciably reduce errors in the estimation of destructively sampled biomass. For example, the standard error in estimating stand biomass for a destructively sampled dataset of trees $\geq 10 \mathrm{~mm} D$ was $12.5 \%$ if an equation including $H$ was used, but $19.5 \%$ when an equation derived without $H$ (but calibrated on the same dataset) was applied (Chave et al., 2005). This same study showed that $H$ was more important than a precipitation-based forest categorisation (dry, moist, wet) in more accurately estimating biomass.

Thus, allometric model choice, rather than sampling error or plot size, may then be the most important source of error in estimating biomass (Chave et al., 2004). With the pantropical destructive biomass dataset sample size restricted by sampling cost and effort, $H$ estimates from regional or continental-scale $H: D$ models may provide a simple way to improve aboveground biomass estimates. Selection of the "best" model form to represent $H$ in biomass models is not straightforward, however, with numerous statistical forms, geographical and environmental parameterisations, and separations by growth form having been tested (e.g., Fang and Bailey, 1998; Feldpausch et al., 2011; Rich et al., 1986; Thomas and Bazzaz, 1999; Banin et al., 2012). In a global tropical analysis using multi-level models to examine the relationship between $H$ and diameter, Feldpausch et al. (2011) grouped plots into regions and found that after taking into account the effects of environment (annual precipitation coefficient of variation, dry season length, and mean annual air temperature) and forest basal area, there were two main regional groups differing in their $H: D$ relationships. Forests in Asia, east, west, and central Africa and the Guiana Shield are all similar in their $H: D$ allometry, but with trees in the forests of much of the Amazon Basin and tropical Australia typically being shorter at any given diameter. Using a similar dataset, but excluding drier forests, Banin et al. (2012), conducted a continental-scale analysis and showed significantly different asymptotic maximum $H$ and allometry among continents after accounting for differences in environment, forest structure and wood specific gravity. These results suggest that either continental or sub-continental geographic $H: D$ patterns may, in addition to model form, be important in reducing error in biomass estimates.

Here, using a large dataset of tree $H$, destructive biomass data (i.e., actual tree biomass is known) and pantropical permanent plot data (where information on $H$ and $D$ is known, but not the true biomass of a plot), we provide a first pantropical evaluation of the effects of $H$ on biomass estimates, including by geographical location (plot, region, and continent). Specifically, we address the following questions:

1. Which is the best $H$-model form and geographic unit for inclusion in biomass models to minimise site-level uncertainty in estimates of destructive biomass?

2. What is the reduction in uncertainty in plot-level biomass estimates based on census data from permanent plots across the tropics when including $H$ ? 
3. How does inclusion of $H$ in biomass estimation protocols modify plot- and continental-level biomass estimates across the tropics?

\section{Methods}

We developed aboveground forest biomass estimates and evaluated biases using tree diameter $(D)$, wood specific gravity $\left(\rho_{\mathrm{W}}\right)$ and tree height $H$ based on destructive sampling and permanent-plot census data. This assessment was completed through the following process: (1) compiling pantropical destructive biomass, tree $H$, and permanent sample plot census data; (2) computing new pantropical biomass models that included or excluded tree $H$; (3) developing models to estimate $H$ from $D$; (4) using the destructive data, evaluated the effect of inclusion or exclusion of actual or simulated $H$ in biomass estimates; (5) applying new biomass models and error estimate from destructive biomass estimates to pantropical plotbased tree census data to (6) determine how biomass estimates change when including $H$; (7) determining the error associated with biomass estimates for pantropical permanent plots; and (8) assessing regional and continental changes in biomass estimates due to $H$ integration in biomass estimates.

Destructive biomass data were compiled from published and non-published data from 20 plots in nine countries (described below). $H$ and $D$ measurements are identical to those in Feldpausch et al. (2011). The tree census data reported here (Fig. 1; Supplement Table S1) are from permanent sample plots, primarily from the RAINFOR (Peacock et al., 2007; Baker et al., 2004a; Phillips et al., 2009) and AfriTRON (Lewis et al., 2009) networks across South America and Africa, respectively, the TROBIT network of forestsavanna transition sites (Torello-Raventos et al., 2012), the CSIRO network in Australia (Graham, 2006), and data from Asia (Banin, 2010) curated in the www.forestplots.net data repository (Lopez-Gonzalez et al., 2011). In addition, for each plot, mean annual precipitation, annual precipitation coefficient of variation, and dry season length were obtained from WorldClim global coverage at 2.5-min resolution based on meteorological station data from 1950-2000 (Hijmans et al., 2005).

\subsection{The destructive dataset}

To determine the efficacy of biomass models to predict biomass, we assembled a destructively sampled tree biomass dataset based on actual cut and weighed tropical forest trees (Chave et al., 2005; Nogueira et al., 2008a; Hozumi et al., 1969; Araújo et al., 1999; Mackensen et al., 2000; Brown et al., 1995; Lescure et al., 1983; Yamakura et al., 1986; Djomo et al., 2010; Henry et al., 2010; Deans et al., 1996; Ebuy et al., 2011; Ketterings et al., 2001; Samalca, 2007). We hereafter refer to this dataset as the "destructive data". The destructive data are pantropical but with relatively few samples from
Africa $(n=116)$. The main differences between the dataset used by Chave et al. (2005) and our dataset are that we excluded mangrove and dry forest biomass data from Chave et al. (2005), and we included recently published destructive biomass datasets from Africa (Ghana, the Democratic Republic of Congo, and Cameroon) (Djomo et al., 2010; Henry et al., 2010; Deans et al., 1996; Ebuy et al., 2011), Kalimantan, Indonesia (Samalca, 2007), and Brazil (Nogueira et al., 2008a). To classify sites, climate data for the destructive dataset were extracted from the WorldClim data based on plot coordinates. For the destructive site data, mean annual precipitation ranged from 1520 to $2873 \mathrm{~mm}$, dry season length 0 to 6 months, $D$ from 1.2 to $1800 \mathrm{~mm}$, and $H$ from 1.9 to $70.7 \mathrm{~m}$.

\subsection{Tree height measurements}

Tree height $(H)$ had been previously measured at many of the permanent census plots from each of the four continents. Methodology and sites are specified in Feldpausch et al. (2011). To summarise the methods, in general a minimum of 50 trees per plot were sampled for $H$ (total tree $H$ above the ground) from $100 \mathrm{~mm}$ binned diameter classes (i.e., 100 to $200,>200$ to $300,>300$ to $400 \mathrm{~mm}$, and $>400 \mathrm{~mm}$ ). For some plots every tree was measured for $H$. Tree $H$ was measured using Vertex hypsometers (Vertex Laser VL400 Ultrasonic-Laser Hypsometer III, Haglöf Sweden), laser range-finders (e.g., LaserAce 300, LaserAce Hypsometer, Leica Disto-5), mechanical clinometers, physically climbing the tree with a tape measure, or by destructive methods. To examine how tree architectural properties related to stem $D$ independently of external factors such as trees damaged by treefalls, trees known to be broken or with substantial crown damage were excluded from analyses. A recent comparison of ground-based methods found that trigonometric methods resulted in either no systematic bias (non-laser method), or resulted in a small underestimate of actual tree height (ground laser-based methods) compared to heights measured from an observational tower (Larjavaara and Muller-Landau, 2012). A second study reported a Pearson correlation of $r^{2}=0.977$ for trigonometry versus laser rangefinder estimates of height (Marshall et al., 2012).

\subsection{Biomass calculations}

Aboveground biomass of trees for each destructively sampled site or permanent sample plot was calculated from a combination of variables. Wood specific gravity, $\rho_{\mathrm{W}}$, was extracted from a global database (http://datadryad.org/handle/ 10255/dryad.235; Zanne et al., 2010; Chave et al., 2009). Where species-specific values were unavailable, we applied genus-level values. Likewise where genus-level values were missing, we applied family-level values. Where tree identification was lacking, we applied the mean $\rho_{\mathrm{W}}$ from all stems in the plot. Based on the moist forest biomass model 


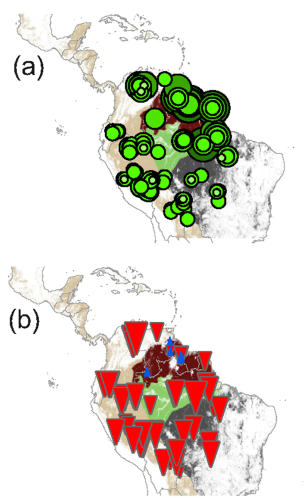

Biomass (Mg/ha)

- 45 to 150

○ 150 to 300

300 to 400

400 to 500

500 to 750

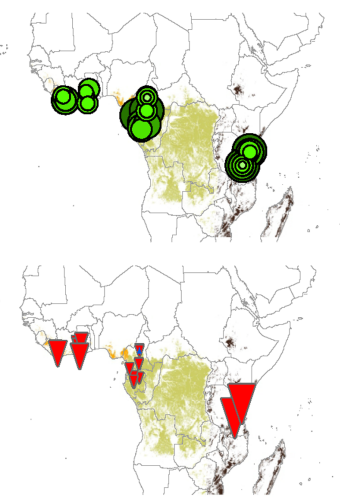

Biomass decrease (Mg/ha)

-195 to -150

V -150 to -100

v -100 to -50

$\checkmark-50$ to -25

V -25 to 0

Biomass increase $(\mathrm{Mg} / \mathrm{ha})$
+1.6 to 5

$4+5$ to 10

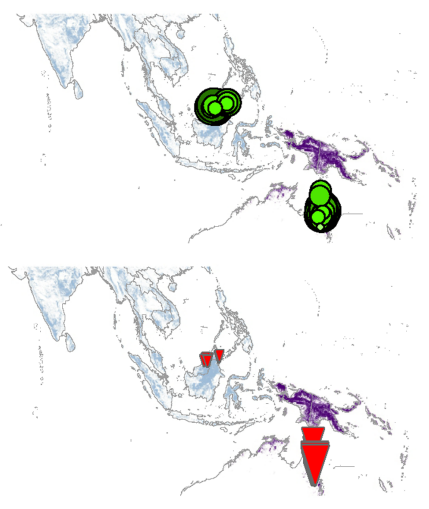

Amazonia, Brazilian Shield

Amazonia, W.-C. America

Amazonia, E.-Central

Amazonia, Guiana Shield

Australasia

Asia

Africa, W.

Africa, central

Africa, $\mathrm{E}$.

Fig. 1. Location of the pantropical permanent plots, including (a) biomass stocks $\left(\mathrm{Mgha}^{-1}\right)$, and (b) change in biomass $\left(\mathrm{Mg}\right.$ ha $\left.{ }^{-1}\right)$ due to inclusion of $H$ in biomass estimates $(B)$ (relative to exclusion of $H)$ for forests $\left(B_{H}-B_{\mathrm{No}-\mathrm{Ht}}\right.$ ) in Africa, Asia, Australia, and South America. Symbols indicate an increase (blue) or decrease (red) in biomass estimates after including $H$ compared to our biomass model Eq. (1) that excludes $H$. See Supplement Table S1 for plot details. Biomass was estimated from the moist forest pantropical models (Table 1) based on tree diameter and wood density, and $H$ (where applicable), with $H$ estimated from Weibull region-specific tree $H$ models (Eq. 5) based on the pantropical tree $H-D$ database shown in Feldpausch et al. (2011). Coloured shading indicates forest cover and different regions used in Figs. 3 and 4.

form proposed by Chave et al. (2005), we developed biomass model (1), as described below, to estimate biomass $(B)$ based on just the measured diameter $(D)$ and estimated $\rho_{\mathrm{W}}$ (i.e., excluding tree $H$ ) using the model form:

$$
\begin{gathered}
B=\exp \left(a+b \ln (D)+c(\ln (D))^{2}\right. \\
\left.-d(\ln (D))^{3}+e \ln \left(\rho_{\mathrm{W}}\right)\right) .
\end{gathered}
$$

Alternatively, using the $H: D$ database developed by Feldpausch et al. (2011), we inferred $H$ using a range of $H: D$ allometric models, and then used that inferred value in bootstrapped biomass model (2) based on the form proposed by Chave et al. (2005) as described below. The model parameterisation, which includes $H$ in addition to diameter and $\rho_{\mathrm{W}}$ is:

$$
B=\exp \left(a+b \ln \left(\rho_{\mathrm{W}} D^{2} H\right)\right) .
$$

\subsection{Biomass error estimation with and without height}

From the destructive dataset, we evaluated the ability of a range of models to estimate biomass $(\mathrm{kg})$ from a combination of $D$ and $\rho_{\mathrm{W}}$, or $D, \rho_{\mathrm{W}}$ and $H$, also examining error distributions across diameter classes and sites. To develop the
$H: D$ allometric relationships for inclusion in biomass models, we used $H$ measurements for individual trees made in 283 plots in 22 countries representing 42656 individual concurrent $H$ and $D$ measurements. Because the global destructive tree biomass dataset was small compared to this and with the distribution of trees in the destructive dataset not necessarily similar in biomass/size distribution of a natural forest, we applied a three-step approach to scale biomass estimates and their associated errors from the destructive dataset to permanent plots and landscape.

1. When biomass models included $H$, we recomputed the regional and continental $H$ models of Feldpausch et al. (2011) to test for their efficacy to reduce error in biomass estimates. These $H$ models were either a nonlinear 3-parameter exponential (Pinheiro et al., 1994; Banin et al., 2012) viz:

$H=a-b(\exp (-c D))$,

or, a model where $H$ scales with $D$ according to a simple power function:

$$
H=a D^{b},
$$


or, alternatively a Weibull function (Bailey, 1979), which takes the form of:

$H=a\left(1-\exp \left(-b D^{c}\right)\right.$.

As there is good evidence of a large difference between different geographical areas in $H: D$ allometry (Feldpausch et al., 2011; Banin et al., 2012), we derived region- and continent-specific parameterisations for each $H: D$ equation and report the residual standard error and Akaike Information Criterion for the selected models (Akaike, 1974). We then tested how these parameterisations of $H$ increased or decreased biomass estimates.

2. To test the effect of the inclusion of $H$ estimates on biomass estimates, we computed a biomass model of all sites with destructively harvested trees, except the site which we wished to estimate. We then estimated the biomass of the trees in the site that was excluded from the model. We then dropped each individual site until all sites were excluded once from model development. The mean relative error in estimated biomass was calculated for each dropped site, where relative error was represented as: $\left(B_{\mathrm{P}}-B_{\mathrm{M}}\right) / B_{\mathrm{M}}$, where $B_{\mathrm{P}}$ is the predicted biomass of a tree (with or without $H$ model) and $B_{\mathrm{M}}$ is the biomass measured by destructive sampling of individual trees.

3. To evaluate how the error from the destructive dataset related to the distribution of trees found in pantropical forests, we estimated biomass for 327 plots from the forest permanent-plot database as described above by locale for tree-diameter classes, providing a biomass distribution by diameter class for each geographic unit (note that the destructive data came from "sites" - sample areas that may not have defined boundaries - while the permanent plot data come from defined-area sample "plots"). We then propagated error from Eqs.(1) and (2) from the destructive dataset to each diameter bin by geographical location and reported the mean relative error for each region. The log-transformation of tree $D$ and biomass data produces a bias in final biomass estimation so that uncorrected biomass estimates are theoretically expected to underestimate the real value (Sprugel, 1983; Baskerville, 1972). This effect can be corrected by multiplying the estimate by a correction factor:

$C_{\mathrm{F}}=\exp \left(\frac{\mathrm{RSE}^{2}}{2}\right)$,

which is always a number greater than 1 , and where RSE is the residual standard error of the regression model.

\subsection{Permanent plot tree census data}

To determine how $H$ integration alters biomass estimates and affects error in biomass estimates, we compiled a pantropical dataset of permanent sample plots (Supplementary Table S1). All plots occurred in intact (minimal recent direct anthropogenic influence) forest, with a minimum plot size of 0.2 ha (mean $=0.95 ; \max =9$ ha) area using standardised sampling methodologies across all sites. Diameters of all live trees and palms ( $\geq 100 \mathrm{~mm}$ diameter at breast height $(D)$ ) were measured to the nearest $1 \mathrm{~mm}$ at $1.3 \mathrm{~m}$ above the ground or $0.5 \mathrm{~m}$ above any buttresses or stilt-roots following international standards of permanent sampling plot protocol (Phillips et al., 2010). Trees were identified by local botanists. For unknown species, vouchers were collected, later identified and archived.

\subsubsection{Africa}

African permanent sample plots $(n=62)$ were grouped into three geographical regions: western, eastern and central Africa. Measurements were made in western Africa in Ghana and Liberia (Lewis et al., 2009; Feldpausch et al., 2011). Central African sites were sampled in central and southern Cameroon, and Gabon (Lewis et al., 2009; Feldpausch et al., 2011). Eastern African sites were established in the Eastern Arc Mountains of Tanzania (Marshall et al., 2012). The number of months with precipitation $<100 \mathrm{~mm}$ per month, based on the estimated average monthly evapotranspiration of a tropical forest (Shuttleworth, 1988) and a widely used index of dry season length (Malhi and Wright, 2004), varies from 1 to 7 months across all sites.

\subsubsection{Asia}

We classified forests in Asia $(n=14)$ as one region for this study, with the division between Asian and Australasian plots according to Lydekker's line (Lohman et al., 2011). Wet and moist forests were sampled in Brunei and Malaysian Borneo (Banin, 2010; Banin et al., 2012). These sites have zero months with mean precipitation $<100 \mathrm{~mm}$ per month.

\subsubsection{Australasia}

Trees were sampled in tropical forest permanent plots $(n=26)$ in northern Australia (Graham, 2006; TorelloRaventos et al., 2012). Precipitation varies over a very short distance from coastal to inland sites, with the dry season length ranging from 4 to 10 months.

\subsubsection{South America}

Tree censuses conducted in plots $(n=225)$ (Baker et al., 2009; Feldpausch et al., 2011; Nogueira et al., 2008b) in South America are grouped here into four regions based on geography and substrate origin (e.g., Fittkau, 1971; 
Schobbenhaus and Bellizzia, 2001): Western Amazonia (Colombia, Ecuador and Peru), with soils mostly originating from recently weathered Andean deposits; Southern Amazonia, encompassing the Brazilian Shield (Bolivia and Brazil); on the opposite side of the Basin to the north, the Guiana Shield (Guyana, French Guiana, Venezuela); and eastern central Amazonia (Brazil), which is mostly comprised of old sedimentary substrates derived from the other three regions (Quesada et al., 2012; Schargel, 2011; Schargel et al., 2001). The number of months with precipitation $<100 \mathrm{~mm}$ per month ranges from 0 to 9 months.

\subsection{Patterns and revision of biomass and carbon stock estimates}

We used a Monte Carlo approach to quantify uncertainty in biomass estimates with and without including $H$, and to extrapolate biomass estimates from plots to the landscape. We accounted for the uncertainty in wood specific gravity $\left(\rho_{\mathrm{W}}\right)$ and $H$ measurements in biomass estimates. For our analysis, we calculated a mean biomass (or carbon) estimate and a $95 \%$ confidence interval for each plot, region, and continent from 1000 realisations of biomass estimates for individual plots. These estimates were based on 1000 realisations of biomass estimates for individual trees in each plot based on the normal distribution of values of the standard error drawn from a random sample for each tree. To estimate biomass for each tree, we used our new biomass models and generated 1000 realisations for each tree by adding error to the $\rho_{\mathrm{W}}$ and $H$ where applicable. The $\rho_{\mathrm{W}}$ of each tree including the error terms was estimated as $\hat{\rho_{\mathrm{W}}}=\rho_{\mathrm{W}}+\chi_{\rho_{\mathrm{W}}} \sigma_{\rho_{\mathrm{W}}}$, and $H$ for each tree including the error terms was estimated as $\hat{H}=H+\chi_{\mathrm{H}}$ $\sigma_{\mathrm{H}}$, where the "^" symbol indicates estimates that necessarily include some error, $\chi$ represents a random value sampled from a distribution with mean $=0$ and standard deviation $=1$, and $\sigma$ represents the standard error of $\rho_{\mathrm{W}}$ or $H$ for a plot. For the realisations of biomass stocks based on forest area, we drew 1000 times from the sample plots for each region. The $95 \%$ confidence interval was calculated as the 2.5 th and 97.5th percentiles of the 1000 realisations of each estimate.

Spatial patterns in plot-level biomass estimates with and without $H$ were examined by region and continent. Based on the regional tropical forest area estimates of broadleaf deciduous open and closed and evergreen tree cover classification from GLC2000 (Global Land Cover Map 2000) (Bartholomé and Belward, 2005) reclassified in ArcGIS ${ }^{\circledR}$ (ESRI, 2010), we scaled bootstrapped regional biomass estimates and uncertainty tropics-wide. Our estimates of tropical forest area are lower than those reported by Mayaux et al. (2005) since we excluded the more open vegetation classes. Biomass was converted to carbon values using a conversion factor of 0.5 (Chave et al., 2005). Statistical analyses were conducted using the $\mathrm{R}$ statistical platform ( $\mathrm{R}$ Development Core Team 2011). Biomass and $H$ models were developed using the lme and nlme functions of R (Pinheiro et al., 2011).

\section{Results}

Using our expanded pantropical destructive biomass dataset (Fig. 2a), we first examine how estimates of real (destructive) biomass data using biomass models (Table 1) are affected by different $H$ model forms and regional or continental parameterisations by examining the relative error by diameter bin (Fig. 2b) and overall bias in biomass estimates by destructively sampled site (Table 2). We next examine how the selected $H$ models (Table 3 ) affect biomass estimates (Fig. 3) and uncertainty (Fig. 4) as a result of regional variation in forest structure (Supplement Table S2) and distribution of biomass among diameter classes for trees measured in pantropical permanent sample plots (Supplement Table S1). Finally, we extrapolate our results to assess the influence of incorporating variations in $H: D$ allometry on regional/continental and global biomass estimates (Tables 4 and 5).

\subsection{How much does the inclusion of height reduce uncertainty in destructive biomass estimates?}

The distribution of destructively sampled aboveground tree dry mass from the available pantropical dataset was roughly equally sampled across the $50 \mathrm{~mm}$ increment diameter classes from $250 \mathrm{~mm}<D \leq 500 \mathrm{~mm}$ but, although involving many more individual trees, somewhat less for $D<250 \mathrm{~mm}$ (Fig. 2a). Although relatively few trees had been sampled for large diameter classes (e.g., 17 trees $\geq 1000 \mathrm{~mm}$ diameter), these larger trees clearly accounted for a significant proportion of the total biomass to be simulated within the dataset. The cumulative biomass in Fig. 2 a represents the nearly $1500 \mathrm{Mg}$ of biomass destructively sampled to date in moist tropical forest which we use to assess the effect of $H$ in biomass estimates. Most of these data have been used in the parameterisation of currently used pantropical biomass models (e.g., Chave et al., 2005), but with newly published data from Africa, Asia, and Brazil included in our analysis.

\subsubsection{Measured heights}

The effect of the inclusion of $H$ using the biomass model forms of Chave et al. (2005) as applied to our dataset are presented in Table 1, where our allometric equations both with and without $H$ included (i.e., Eqs. 1 and 2) are compared. This shows that applying Eq. (1) (which excludes $H$ ) resulted in considerably higher residual standard error (RSE) and Akaike information criteria (AIC) estimates than when $H$ was included (Eq. 2).

\subsubsection{Simulated heights}

The effects of substituting estimates of $H$ from Eqs. (3-5) into Eq. (2) are shown in Table 2. The inclusion of $H$ improved site-level estimates of aboveground biomass, bringing them closer to the known destructive harvest values, with 
a)
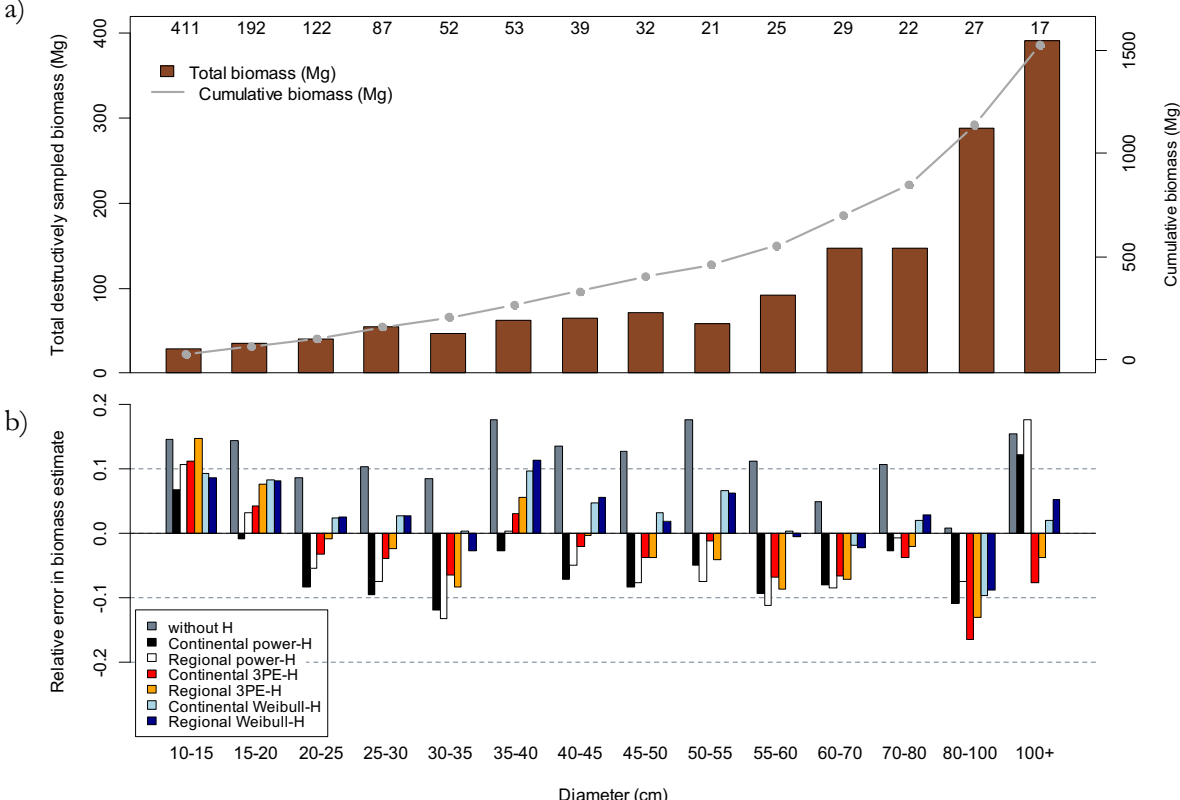

Fig. 2. (a) Distribution of destructively sampled aboveground tree dry mass (bars) by diameter class (cm) and cumulative biomass (line) on the second axis. Numbers above the bars indicate the number of trees sampled. The dataset represents the pantropical destructive data to date used to form biomass allometric models, including additional data from Africa, Asia, and South America. (b) Relative error associated with estimating the true (destructively) sampled aboveground tree dry mass $\left(\left(B_{\text {estimated }}-B\right.\right.$ measured $\left.) / B_{\text {measured }}\right)$ for the same dataset estimated with and without estimated $H$ in the biomass model by diameter class $(\mathrm{cm})$. Height estimated by three model forms and either a continental or regional parameterisation. Positive values indicate the biomass model overestimates true destructively sampled mass.

Table 1. Pantropical models to estimate dry biomass $(\mathrm{kg})$ from Eq. $(1)$, diameter $(D, \mathrm{~cm})$ and wood specific gravity $\left(\rho \mathrm{W}, \mathrm{g} \mathrm{cm}{ }^{-3}\right)$, and Eq. (2), also including tree height $(H, \mathrm{~m})$ for trees in pantropical forests; including the residual standard error (RSE), Akaike information criterion (AIC) and number of trees $(n)$ based on destructively sampled moist forest tree data from Africa, Asia, and South America.

\begin{tabular}{|c|c|c|c|c|c|c|c|c|c|}
\hline Model & $a$ & $b$ & $c$ & $d$ & $e$ & RSE & $R^{2}$ & AIC & $n$ \\
\hline \multicolumn{10}{|c|}{ Eq. $(1): \ln (B)=a+b \ln (D)+c(\ln (D))^{2}+d(\ln (D))^{3}+e \ln \left(\rho_{\mathrm{W}}\right)$} \\
\hline & -1.8222 & 2.3370 & 0.1632 & -0.0248 & 0.9792 & 0.3595 & 0.973 & 1444 & 1816 \\
\hline \multicolumn{10}{|c|}{ Eq. (2): $\ln (B)=a+b \ln \left(D^{2} \rho_{\mathrm{W}} H\right)$} \\
\hline & -2.9205 & 0.9894 & - & - & - & 0.3222 & 0.978 & 1044 & 1816 \\
\hline
\end{tabular}

a relative error of 0.06 for both the Weibull- $H$ region and continent-specific $H$ models (Table 2). Excluding $H$ tended to produce overestimated aboveground biomass estimates, with a relative error of 0.13 . Regionally derived $H$ estimates were non-significantly better than continental scale derived $H$ estimates at predicting site-level biomass (Table 2).

Specifically, the Weibull- $H$ (Eq. 5) (Table 3) consistently reduced the relative error in biomass estimates over all diameter classes as compared to the non- $H$ estimates. This contrasted with the power- $H$ model (Eq. 4), which although reducing error even further in some diameter classes, had greater error for other diameter classes, even greater than those derived from Eq. (1) which excludes $H$ (Fig. 2b). The power- $H$ model also had greater error for small diameter classes. Hence, overall, we consider that the Weibull model modestly outperformed the other two function forms of $H: D$ relationships, and utilise this relationship (Table 2).

\subsection{Improving biomass estimates from permanent sample plots}

\subsubsection{Effect of including height in biomass estimates}

Integration of the region-specific Weibull- $H$, on average, reduced estimated biomass per plot $(B)$ relative to excluding $H$ in biomass estimates by $-52.2(-82.0$ to $-20.3 \mathrm{Mg}$ dry mass $\mathrm{ha}^{-1}$ bootstrapped $95 \% \mathrm{CI}$ ) (Figs. $1 \mathrm{~b}$ and 3, Table 4). As shown by the cumulative biomass curves in Fig. 3, including $H$ in biomass estimates did not affect all regions equally. For South America, including $H$ significantly reduced biomass estimates for all regions (by 

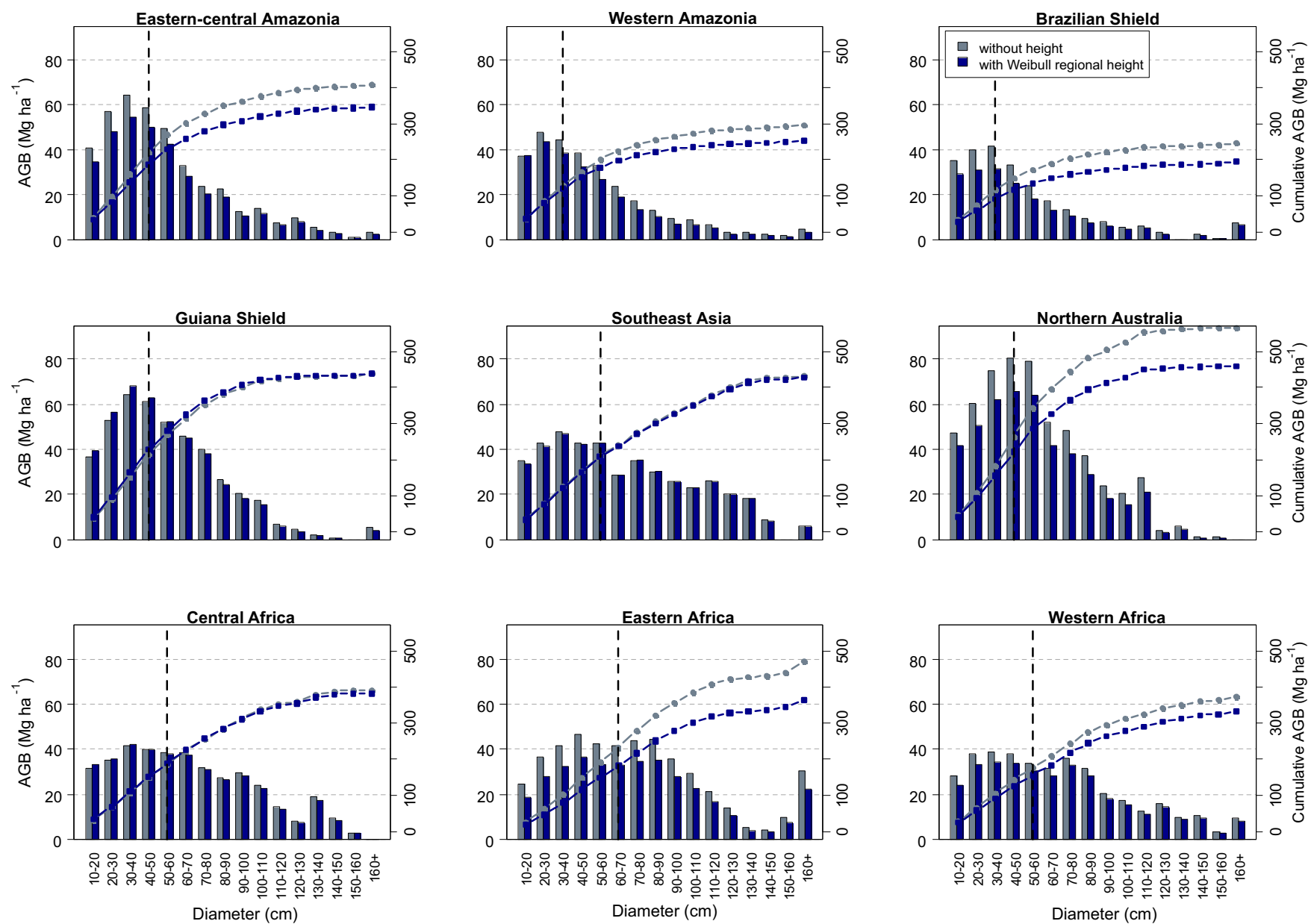

Fig. 3. Biomass $\left(\mathrm{Mg} \mathrm{ha}^{-1}\right)$ distribution (bars) among diameter class $(\mathrm{cm})$ by region with cumulative aboveground biomass $(\mathrm{AGB})\left(\mathrm{Mg}\right.$ ha $\left.{ }^{-1}\right)$ on the second axis (lines) for trees in pantropical permanent plots. Tree-by-tree biomass was estimated by model (1) without $H$, or model (2) with Weibull (Eq. 5) region-specific $H$. The vertical dashed line represents the mid-point in biomass storage above and below the indicated diameter bin. See Table 4 for differences in biomass estimates due to $H$ integration.

$-55.9,-66.6$, and $-48.0 \mathrm{Mg} \mathrm{ha}^{-1}$ for the Brazilian Shield, east-central Amazonia and western Amazonia, respectively) (paired t-test, $p<0.001$ ). East and west Africa, and northern Australia also had significantly lower biomass estimates when including $H\left(-107.9,-44.2,-116.5 \mathrm{Mg} \mathrm{ha}^{-1}\right.$, respectively). Southeast Asia, central Africa, and the Guiana Shield of South America had small but significant reductions in biomass estimates when including $H$ (paired t-test, $p<0.001$ ). No region had significantly higher biomass estimates after including $H$ (see Supplement, Table S1, for $\Delta$ biomass estimates for all plots).

\subsubsection{Differences in biomass distribution among regions}

Forests store a large fraction of total biomass in smaller diameter stems, with appreciable differences in the biomass distribution among diameter classes reflecting strong regional patterns (Fig. 3). For example, forests of the four regions of South America had a significantly $(p<0.05)$ larger fraction of total biomass in smaller size classes $(\leq 40 \mathrm{~cm}$ $D$ ) compared to the three regions of Africa and Asia. This is shown graphically in Fig. 3 by the cumulative biomass curves, where forests of some regions approach an asymptote in cumulative biomass at larger diameter classes. The vertical dashed line in Fig. 3 represents the mid-point in biomass storage above and below the indicated diameter bin.

It is because of the skewed biomass distributions of Fig. 3 with a concentration of biomass in smaller diameter classes in most forests (e.g., $\leq 40$ to $60 \mathrm{~cm} D$ ) that in Sect. 3.1 we chose the Weibull- $H$ model, which has lower relative error in small diameter classes (in contrast to the power- $H$ model and three-parameter exponential model), and therefore has the greatest plot-level effect in reducing uncertainty. After accounting for regional tree $H$ differences, total biomass per hectare is thus estimated to be greatest in Australia, the Guiana Shield, and Asia and lowest in west Africa, 

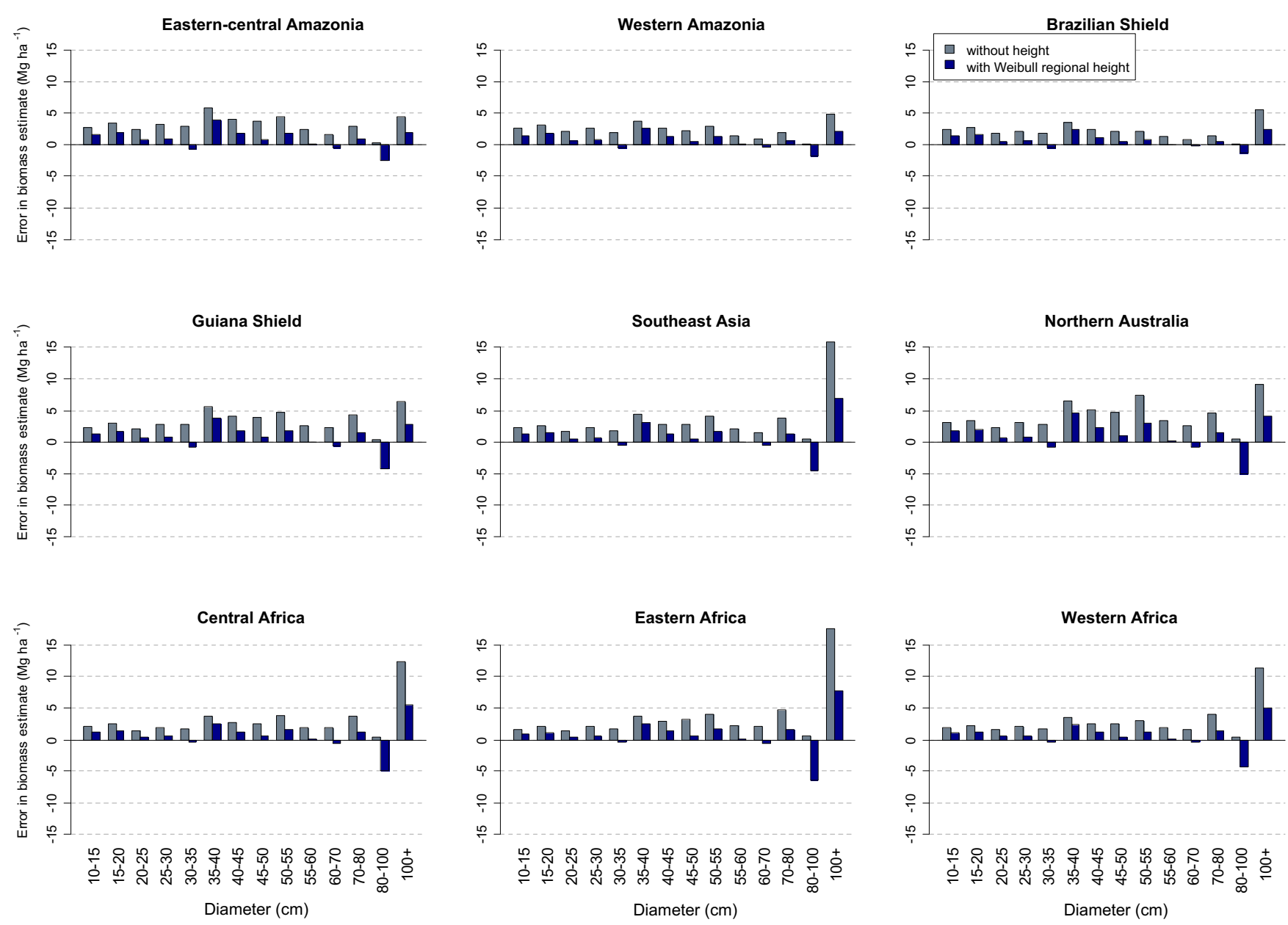

Fig. 4. Error in biomass estimates $\left(\mathrm{Mg} \mathrm{ha}^{-1}\right)$ for trees in pantropical permanent plots due to biomass model inputs excluding or including $H$ (relative error propagated from destructive data). Tree-by-tree biomass was estimated by model (1) without $H$, or model (2) with Weibull (Eq. 5) region-specific $H$.

west Amazonia, and the Brazilian Shield (descending order) (Table 4).

\subsubsection{Estimating effects of $H$ on errors in permanent sample plot biomass estimates}

To estimate error in permanent plots due to error in destructive measurements, we multiplied the relative error from the diameter bin from the small sample of destructive measurements for the Weibull- $H$ model (Eqs. 2 and 5), as shown in Fig. $2 b$, by the biomass of the equivalent size class in each of the pantropical permanent plots. This relative error in fieldbased plots was greater when the same procedure was undertaken for the "no- $H$ " Eq. (1) (Fig. 4). Specifically, by including $H$, the error in estimates is reduced in small diameter classes but not large diameter classes. This is because of the increasing absolute errors of the Weibull- $H$ model for the larger trees. The mean error in biomass estimates for all regions when including Weibull- $H$ in biomass estimates was an overestimate of $8.0 \mathrm{Mg} \mathrm{ha}^{-1}$, a value considerably less than the calculated overestimate of $41.8 \mathrm{Mg} \mathrm{ha}^{-1}$ when $H$ was excluded (Fig. 4). The alternative two $H$ models of Eqs. (3) and (4) were also tested and found to underestimate biomass by -8.2 and $-5.5 \mathrm{Mg} \mathrm{ha}^{-1}$, respectively. Overall, inclusion of Weibull- $H$ (Eq. 5) in biomass estimates for tropical forest plots resulted in a smaller mean bias in biomass estimates compared to when $H$ was omitted. Specifically the bias with $H$ included ranged from 6 to $9.5 \mathrm{Mg} \mathrm{ha}^{-1}$ (South America), 10.1 to $10.6 \mathrm{Mg} \mathrm{ha}^{-1}$ (Asia and Australia), and 5.3 to $7.3 \mathrm{Mg} \mathrm{ha}^{-1}$ (Africa), as compared to estimation without $H$ which had biases of 28.6 to $47.2 \mathrm{Mg} \mathrm{ha}^{-1}$ (South America), 48.9 to $63.2 \mathrm{Mg} \mathrm{ha}^{-1}$ (Asia and Australia), and 40.5 to 49.4 $\mathrm{Mg} \mathrm{ha}^{-1}$ (Africa) (Fig. 4).

\subsection{Effect on pantropical carbon estimates}

Based on published estimates of tropical forest area (GLC2000), and biomass and carbon estimated in our 
Table 2. Efficacy of biomass models including or excluding tree $H$ to predict true (destructively) sampled biomass for trees $\geq 10$ $\mathrm{cm} D$ for individual sites excluded from model formulation. Values represent bootstrapped mean relative error, or bias $\left(\left(B_{\text {predicted }}-\right.\right.$ $\left.B_{\text {measured }}\right) / B_{\text {measured }}$ ), for a site, in dry biomass estimated from a biomass model excluding $H$ (Eq. 1 ), and biomass including $H$ (Eq. 2 ) using various $H$ models (Eqs. 3-5) based on region- and continent-specific $H$ models. Values in bold indicate the model with the lowest mean relative error (bias) for a site (this excludes the power model, which although it has the lowest overall bias and standard deviation, fails to reduce error in the small diameter classes).*

\begin{tabular}{|c|c|c|c|c|c|c|c|c|c|c|c|}
\hline \multirow[b]{2}{*}{ Dropped Site** } & \multirow[b]{2}{*}{ Location } & \multirow[b]{2}{*}{ Region } & \multirow[b]{2}{*}{$n$} & \multicolumn{2}{|c|}{$3 \mathrm{PE}$} & \multicolumn{2}{|c|}{ Weibull } & \multicolumn{2}{|c|}{ Power } & \multirow[t]{2}{*}{ No Ht } & \multirow[t]{2}{*}{ Data source } \\
\hline & & & & Continent & Region & Continent & Region & Continent & Region & & \\
\hline BraCot & Cotriguaçu, Pará, Brazil & Brazilian Shield & 151 & 0.01 & -0.02 & 0.01 & -0.09 & -0.04 & -0.07 & 0.09 & Nogueira et al. (2008a) \\
\hline BraJuruena & Juruena, Mato Grosso, Brazil & Brazilian Shield & 49 & -0.04 & -0.06 & -0.05 & -0.13 & -0.08 & -0.11 & 0.05 & Nogueira et al. (2008a) \\
\hline BraMan1 & Manaus, Amazonas, Brazil & E.-Central Amazonia & 315 & 0.01 & -0.07 & -0.05 & -0.14 & -0.05 & -0.13 & -0.01 & Chave et al. (2005) \\
\hline BraMan2 & Manaus, Amazonas, Brazil & E.-Central Amazonia & 123 & 0.05 & -0.03 & 0.04 & -0.06 & 0.00 & -0.09 & 0.13 & Chave et al. (2005) \\
\hline BraNPro & $\begin{array}{l}\text { Novo Progesso, Mato Grosso, } \\
\text { Brazil }\end{array}$ & Brazilian Shield & 64 & -0.22 & -0.23 & -0.25 & -0.30 & -0.25 & -0.28 & -0.20 & Nogueira et al. (2008) \\
\hline BraPara1 & Tomé Açu, Pará, Brazil & Brazilian Shield & 127 & -0.04 & -0.12 & -0.02 & -0.10 & -0.08 & -0.16 & 0.07 & Araujo et al. (1999) \\
\hline BraPara3 & Belem, Pará, Brazil & Brazilian Shield & 21 & -0.14 & -0.21 & -0.09 & -0.16 & -0.18 & -0.25 & 0.01 & Chave et al. (2005) \\
\hline BraRond & Rôndonia, Brazil & Brazilian Shield & 8 & -0.50 & -0.53 & -0.46 & -0.53 & -0.52 & -0.54 & -0.39 & Brown et al. (1995) \\
\hline FrenchGu & Piste St. Elie, French Guiana & Guiana Shield & 360 & 0.48 & 0.77 & 0.37 & 0.53 & 0.40 & 0.73 & 0.47 & Chave et al. (2005) \\
\hline Llanosec & Llanos secondary & Western Amazonia & 24 & 0.47 & 0.79 & 0.45 & 0.66 & 0.40 & 0.73 & 0.61 & Chave et al. (2005) \\
\hline Llanosol & Llanos old-growth & Western Amazonia & 27 & 0.10 & 0.35 & 0.17 & 0.35 & 0.07 & 0.35 & 0.32 & Chave et al. (2005) \\
\hline CamCampo-Ma'an & Campo-Ma'an, Cameroon & Central Africa & 71 & 0.15 & 0.34 & -0.01 & 0.22 & 0.03 & 0.24 & 0.13 & Djomo et al. (2010) \\
\hline CamMbalmayo & Mbalmayo, Cameroon & Central Africa & 4 & 0.09 & 0.11 & 0.15 & 0.29 & 0.04 & 0.05 & 0.33 & Deans et al. (1996) \\
\hline DRCYangambi & $\begin{array}{l}\text { Yangambi, Democratic Republic } \\
\text { of Congo }\end{array}$ & Central Africa & 12 & -0.07 & -0.04 & -0.01 & 0.12 & -0.13 & -0.11 & 0.13 & Ebuy et al. (2011) \\
\hline GhaBoiTano & Boi Tano, Ghana & Western Africa & 41 & -0.18 & -0.14 & -0.13 & -0.13 & -0.14 & -0.10 & -0.01 & Henry et al. (2010) \\
\hline Kaliman1 & Kalimantan, Balikpapan, Indonesia & South-east Asia & 23 & -0.04 & -0.04 & -0.02 & -0.02 & -0.07 & -0.07 & 0.01 & Chave et al. (2005) \\
\hline Kaliman2 & Kalimantan, Sebulu, Indonesia & South-east Asia & 69 & $-\mathbf{0 . 1 1}$ & -0.11 & -0.18 & -0.18 & -0.15 & -0.15 & -0.13 & Yamakura et al. (1986) \\
\hline Kaliman3 & $\begin{array}{l}\text { PT Hutan Labanan Sanggam Lestari, } \\
\text { Kalimantan, Indonesia }\end{array}$ & South-east Asia & 40 & -0.08 & -0.08 & -0.07 & -0.07 & -0.12 & -0.12 & -0.03 & Samalca (2007) \\
\hline Pasoh-01 & Pasoh, Malaysia & South-east Asia & 139 & -0.07 & -0.07 & -0.13 & -0.13 & -0.11 & -0.11 & -0.09 & Chave et al. (2005) \\
\hline Sumatra & Sepunggur, Sumatra, Indonesia & South-east Asia & 29 & 0.27 & 0.27 & 0.26 & 0.26 & 0.22 & 0.22 & 0.33 & Ketterings et al. (2001) \\
\hline Relative error & & & & 0.03 & 0.05 & 0.06 & 0.06 & -0.01 & 0.02 & 0.13 & \\
\hline Std. Dev. & & & & 0.25 & 0.33 & 0.22 & 0.29 & 0.23 & 0.32 & 0.25 & \\
\hline
\end{tabular}

* Biomass estimated from models based on tree diameter, wood density (Eq. 1) and where applicable, $H$ (Eq. 2). Height is estimated from models developed from the pantropical tree $H$-D database of Feldpausch et al. (2011). ** Efficacy of the biomass model to predict biomass was independently assessed for each "dropped site" which was excluded from the development of the biomass model.

permanent plot networks, we calculated the change in regional and continental aboveground live tree carbon stocks due to integration of $H$ in biomass models. Using GLC2000 (Bartholomé and Belward, 2005) tropical forest categories and mean carbon storage in each region from the plot data, the tropical Americas had the largest reduction $-17.1 \mathrm{PgC}$ $(-18.5$ to -15.6 bootstrapped $95 \% \mathrm{CI}),-14 \%$ in estimated carbon storage due to $H$, and Asia, $-1 \mathrm{PgC}(-1.1$ to -0.8 bootstrapped $95 \% \mathrm{CI}),-2 \%$, the smallest. Inclusion of region-specific $H$ models to estimate carbon reduced tropics-wide estimates of total carbon in tropical forests from 320.5 Pg C (282.4-358.6 bootstrapped 95\% CI) to $285.1 \mathrm{PgC}(251.8-318.9$ bootstrapped $95 \% \mathrm{CI})$, a reduction of $-35.2 \mathrm{Pg} \mathrm{C}(-39.4$ to -30.7 bootstrapped $95 \% \mathrm{CI})$, or $13 \%$, relative to when $H$ was included (Table 5 ).

\section{Discussion}

We show that (1) including $H$ significantly improves the accuracy of estimation of tropical forest aboveground biomass; (2) failing to include $H$ usually causes an overestimate of biomass; (3) such overestimates may have globally significant implications - here we estimate that carbon storage in tropical forests may be overestimated by 13\%; and finally we recommend that (4) continental or regional-specific asymptotic Weibull $H: D$ functions to be included in future estimates of biomass to reduce uncertainty in aboveground biomass estimates in tropical forests. Below, we discuss some of the sources of variability in biomass and $H$ estimates, limitations of these models, and implications for pantropical scaling and carbon valuation under REDD+.

\subsection{Compensating for imperfect biomass models}

\subsubsection{Representing height in biomass estimates}

In this study we selected the $H$ model based on the regionspecific parameterisation of the Weibull- $H$ (Eq. 5) model because it reduced error in estimating biomass for the smaller diameter classes (Fig. 2b), which constitute a large part of the plot-level biomass (Fig. 3). Although the Weibull- $H$ form is less than ideal for trees of $800-1000 \mathrm{~mm}$ diameter, the three-parameter exponential (Eq. 3) and power- $H$ models (Eq. 4) were not significantly better biomass estimators for the largest trees (Fig. 2b). This may be because the parameterisation of the Weibull- $H$ model should theoretically account for some of the asymptotic nature of tree growth more than the power- $H$ or 3-parameter exponential $H$ models. In general, however, asymptotic $H$ has not been detected as often as may be expected among species growing in tropical forest (Poorter et al., 2006; Chave et al., 2003; Davies et 
Table 3. Coefficients for Weibull- $H$ region-, continent-specific and pantropical models $\left(H=a\left(1-\exp \left(-b D^{c}\right)\right)\right)$ to estimate tree height $(H$, $\mathrm{m}$ ) from diameter $(D, \mathrm{~cm}) \geq 10 \mathrm{~cm}$ in pantropical forests, including the residual standard error (RSE), Akaike information criterion (AIC), and number of trees $(n)^{*}$.

\begin{tabular}{lllllllr}
\hline Continent & Region & $a$ & $b$ & $c$ & RSE & AIC & $n$ \\
\hline Africa & & 50.096 & 0.03711 & 0.8291 & 5.739 & 75422 & 11910 \\
& C. Africa & 50.453 & 0.0471 & 0.8120 & 6.177 & 16671 & 2572 \\
& E. Africa & 43.974 & 0.0334 & 0.8546 & 5.466 & 10343 & 1658 \\
& W. Africa & 53.133 & 0.0331 & 0.8329 & 5.165 & 47020 & 7680 \\
\hline \multirow{2}{*}{ S. America } & & 42.574 & 0.0482 & 0.8307 & 5.619 & 121167 & 19262 \\
& Brazilian Shield & $227.35^{* *}$ & 0.0139 & 0.5550 & 4.683 & 20639 & 3482 \\
& E. C. Amazonia & 48.131 & 0.0375 & 0.8228 & 4.918 & 39688 & 6588 \\
& Guiana Shield & 42.845 & 0.0433 & 0.9372 & 5.285 & 32491 & 5267 \\
& W. Amazonia & 46.263 & 0.0876 & 0.6072 & 5.277 & 24201 & 3925 \\
\hline Asia & S. E. Asia & 57.122 & 0.0332 & 0.8468 & 5.691 & 18623 & 2948 \\
\hline Australia & N. Australia & 41.721 & 0.0529 & 0.7755 & 4.042 & 48073 & 8536 \\
\hline Pantropical & & 50.874 & 0.0420 & 0.784 & 5.479 & 266169 & 42656 \\
\hline
\end{tabular}

* Models adapted from the pantropical tree $H: D$ database of Feldpausch et al. (2011).

** Although an unrealistic asymptotic maximum $H$ coefficient $(a)$, trees of 10 and $160 \mathrm{~cm}$ diameter would have an estimated $H$ of 11.1 and $47.2 \mathrm{~m}$, respectively, with this model.

al., 1998; Thomas, 1996; Iida et al., 2011); only one-fourth of species in sites sampled in Bolivia reached an asymptote (Poorter et al., 2006). However, asymptote detection is likely to be, in part, sample size dependent. Unlike the power model, the 3-parameter exponential and Weibull functions for tree $H$ have an additional biologically meaningful parameter with a term for maximum tree height $\left(H_{\max }\right)$ here being applied at the plot, regional, or continental (as opposed to species) level, and it is for this reason that the $H_{\max }$ should be interpreted carefully. For example, when pooling the transitional forests from our study for the Brazilian Shield of Amazonia, the Weibull- $H$ model converged on a $H_{\max }$ beyond the observable tree size range, and thus spurious, large $H_{\max }$ parameters may be obtained (e.g., $>200 \mathrm{~m}$ ). This model, however, gives an estimate of 11 and $47 \mathrm{~m}$ for trees of 100 and $1600 \mathrm{~mm}$ diameter, respectively, demonstrating that although the model provides realistic values, use of $H_{\max }$ alone to describe stand properties could give erroneous interpretations. For some forests, the power- $H$ model provides a better fit for large-diameter trees (Feldpausch et al., 2011), and in the current study the power model resulted in a lower mean error in estimating destructive tree biomass. With a goal of reducing error in biomass estimates at the stand-level, the asymptotic model form - which reduces error in small-diameter trees outperforms the power model because of the skewed distribution of stand-level biomass found in smaller-diameter trees, and was, therefore, chosen (Fig. 3).

Independent of $H$ model form, no current regional-scale $H$ models are parameterised to account for successional variation of tropical forest trees. Secondary forest trees are frequently taller for a given $D$ (Montgomery and Chazdon, 2001). Mechanical effects can also modify small patches of forest over large areas, where, for example, bamboo can modify $H: D$ relationships (Griscom and Ashton, 2006) and wind may alter forest structure (Laurance and Curran, 2008). Our $H$ models were developed from the most comprehensive dataset to date, which includes a range of forest types including bamboo and liana forests. Developing site- or forestspecific $H$ models is one alternative to account for localised variations in forest structure but requires substantial cost and field time to develop. Development of plot-level basal area-weighted height estimates (i.e., Lorey's height) would also aid in validating remote sensing biomass estimates (e.g., Saatchi et al., 2011).

\subsubsection{Modelling destructive biomass data}

Examination of Fig. $2 b$ raises two questions: "Why does exclusion of $H$ in biomass estimates largely overestimate true biomass?" and "Why are biomass models unable to reduce error in large trees?" It was previously noted that pantropical biomass models overestimate biomass in large trees (Chave et al., 2005). Some of this error was attributed to the lack of sampling in large trees (Chave et al., 2004); however, close inspection of Fig. 4 in Chave et al. (2005) shows that biomass of the smallest trees (e.g., $<100 \mathrm{~mm}$ diameter) is also underestimated (with these trees having the largest sample size). This suggests a different biomass model functional form may be necessary to remove the positive bias of trees $\geq 100 \mathrm{~mm}$ diameter either with or without including $H$. Other studies have confirmed that the model functional form we use (Eqs. 1 and 2) provides a better fit than other parameterisations (e.g., Vieilledent et al., 2012). 
Table 4. Pantropical live tree aboveground dry biomass $(B)$ estimates (mean $\left(\mathrm{Mg} \mathrm{ha}^{-1}\right)$ and bootstrapped $\left.95 \% \mathrm{CI}\right)$ when calculated as column (a) biomass estimated as per most published studies excluding $H$ using our recalculation of the Chave et al. (2005) model with new published data; (b) biomass estimated based on height $(H)$ integration from a regional $H$ model; and (c) the difference (b-a) in biomass due to $H$ integration for 327 plots.

\begin{tabular}{llrrrr}
\hline Continent & Region & $n$ plots & (a) no $H^{*}$ & (b) with $H *$ & (c) $\Delta B$ due to $H$ \\
\hline \multirow{2}{*}{ Africa } & C. Africa & 16 & $392.9(122.3-570.1)$ & $379.4(124.1-547)$ & $-13.5(-24.3-1.8)$ \\
& E. Africa & 20 & $470.3(213.5-760.7)$ & $362.4(163.4-591.8)$ & $-107.9(-168.9--50.1)$ \\
& W. Africa & 26 & $374.4(229.3-458.3)$ & $330.2(199.6-405.1)$ & $-44.2(-54.6--29.7)$ \\
\hline \multirow{2}{*}{ S. America } & Brazilian Shield & 35 & $250.3(138.2-377.2)$ & $194.5(108.2-308.8)$ & $-55.9(-74.8--30.0)$ \\
& E. C. Amazonia & 44 & $410.7(280.8-604.7)$ & $344.1(237.3-509.7)$ & $-66.6(-94.3--43.7)$ \\
& Guiana Shield & 45 & $441.1(293.9-763.4)$ & $434.4(291.2-728.4)$ & $-6.7(-35.3-12.6)$ \\
& W. Amazonia & 101 & $299.6(162.4-484.9)$ & $251.7(141.5-391.9)$ & $-48.0(-90.8--14.7)$ \\
\hline Asia & S. E. Asia & 14 & $434.6(266.8-669.7)$ & $424.2(259.2-655.3)$ & $-10.5(-15.6--5.8)$ \\
\hline Australia & N. Australia & 26 & $571.8(138.9-857.1)$ & $455.3(116.0-678.0)$ & $-116.5(-179.0--22.9)$ \\
\hline Grand mean & & & $405.1(205.1-616.2)$ & $352.9(182.3-535.1)$ & $-52.2(-82.0--20.3)$ \\
\hline
\end{tabular}

* Biomass estimated from the moist forest pantropical model based on tree diameter and $\rho_{\mathrm{W}}$ or based on tree diameter, $\rho_{\mathrm{W}}$ and $H$, where $H$ is estimated from Weibull region-specific tree $H$ models based on the pantropical tree $H: D$ database from Feldpausch et al. (2011). Region geographic extent is shown in Fig. 1.

The challenge to reduce uncertainty in biomass estimates of large-diameter trees (e.g., $\geq 800 \mathrm{~mm}$ diameter) can be understood by examining the destructively sampled trees. Trees from this diameter class have an enormous variation in mass, from 4.6 to $70.2 \mathrm{Mg}$ (mean $15.3 \mathrm{Mg}$ ); similarly, a wide range of wood specific gravity, 0.26 to $0.9 \mathrm{~g} \mathrm{~cm}^{3}$ (mean 0.56); and vary in $H$ from 32 to $71 \mathrm{~m}$ (mean 46). These differences may represent the substantial variation in lifestrategies among "emergent" canopy species, where large diameter low-density light demanding trees coexist with shade tolerant species. Thus, not only larger sample sizes of large size trees are needed, but in the future perhaps two differing equations for differing life history strategies will be required (e.g., see Henry et al. (2010), for some data analysed in this way).

Clearly, greater collaboration is required to sample trees and unify the many destructively sampled tree datasets into one database to improve regional or pantropical biomass equations with inclusion of $H$. Our study provides a first step in dissecting one component of this variation (regional $H: D$ relationships) to revise tropical biomass estimates, e.g., we show that regions differ in their distribution of biomass among $D$ class (Fig. 3), and that as a result, effects of inclusion of $H$ estimates on predicted biomass values vary strongly from region to region (Table 5).

\subsubsection{Regional and continental differences}

While noting the limited sample sizes for some regions, we show that forest biomass, after taking $H$ into account, was highest in Australian forests. Biomass was as high in the Guiana Shield as in SE Asian forests, which is inconsistent with the view from previous studies that have suggested that aboveground biomass storage is higher in Southeast Asia (e.g., Slik et al., 2010). In addition, regional adjustments in biomass estimates due to elevation and tree $H$ may be necessary for some areas. For example, tree $H$ varies with elevation in Tanzania, with the tallest trees at mid-elevation (Marshall et al., 2012).

We found substantially different biomass distribution among diameter classes between the forests of South America and Australia, and Africa and SE Asia, which affected error propagation and determined $H$ model selection. Forests of South America have a greater proportion of the total biomass in the smaller size classes $\leq 40 \mathrm{~cm} D$; flatter distributions are found in Africa and Asian forests, with East African forests showing the lowest proportion of biomass in small size classes (22\%) (Fig. 3). With the exception of the Guiana Shield, these regional patterns broadly correspond to reported differences in the relationship in $H: D$ allometry (Feldpausch et al., 2011). Larger sample sizes are needed to assess whether these biomass distribution differences are consistent when expanded beyond the regional clusters. The Weibull- $H$ model was selected because it reduced uncertainty in the smallest diameter size classes, which for most forests hold a large part of the biomass. As a result of the large region-to-region variation in biomass distribution among diameter classes (Fig. 3), future work may indicate that other $H$ forms are more effective in reducing uncertainty in forests that contain different biomass distribution among diameter classes.

Feldpausch et al. (2011) used a similar regional analysis, and showed a group of tall-stature forests (African, Asia and Guiana Shield) and other lower-statured forests (Amazon and Australia), while Banin et al. (2012) reported significant 
Table 5. Stocks and change in estimated pantropical $\mathrm{C}$ in aboveground live trees (mean and bootstrapped $95 \% \mathrm{CI}$ ) due to $H$ integrated into biomass estimates based on region-specific estimates of tree $H$, compared to the pantropical forest biomass model that excludes $H^{*}$.

\begin{tabular}{|c|c|c|c|c|c|c|}
\hline \multirow{3}{*}{ Continent } & \multirow{3}{*}{ Region } & \multirow{3}{*}{$\begin{array}{r}\text { Area } \\
\left(10^{6} \mathrm{ha}\right)\end{array}$} & \multirow{3}{*}{$\begin{array}{r}\text { without height } \\
\text { Total C } \\
(\mathrm{Pg})\end{array}$} & \multirow{3}{*}{$\begin{array}{r}\text { with height } \\
\text { Total C } \\
(\mathrm{Pg})\end{array}$} & \multicolumn{2}{|c|}{$\Delta \mathrm{C}$ due to height - } \\
\hline & & & & & Total C & $\begin{array}{l}\text { Relative } \\
\text { reduction }\end{array}$ \\
\hline & & & & & $(\mathrm{Pg})$ & \\
\hline \multirow[t]{4}{*}{ Africa } & C. Africa & 422.6 & $83.0(68.4-96.7)$ & $80.2(66.6-93.2)$ & $-2.9(-3.7--2.0)$ & -0.03 \\
\hline & E. Africa & 123.1 & $29.0(25.0-33.3)$ & $22.3(19.1-25.6)$ & $-6.6(-7.5--5.7)$ & -0.23 \\
\hline & W. Africa & 69.8 & $13.1(12.1-13.9)$ & $11.5(10.7-12.3)$ & $-1.5(-1.6--1.4)$ & -0.12 \\
\hline & Total & 615.6 & $125.1(105.5-143.9)$ & $114.0(96.4-131.1)$ & $-11.0(-12.8--9.1)$ & -0.13 \\
\hline \multirow{5}{*}{$\begin{array}{l}\text { South- } \\
\text { Central } \\
\text { America }\end{array}$} & Brazilian Shield & 220.9 & $27.7(25.4-30.0)$ & $21.5(19.7-23.4)$ & $-6.2(-6.6--5.7)$ & -0.22 \\
\hline & E. C. Amazonia & 106.2 & $21.8(20.4-23.3)$ & $18.3(17.1-19.4)$ & $-3.5(-3.8--3.3)$ & -0.16 \\
\hline & Guiana Shield & 148.3 & $32.7(30.0-35.6)$ & $32.2(29.7-34.6)$ & $-0.5(-0.8--0.2)$ & -0.02 \\
\hline & W. Amazonia & 286.4 & $42.9(41-44.9)$ & $36.0(34.5-37.5)$ & $-6.9(-7.3--6.4)$ & -0.16 \\
\hline & Total & 761.9 & $125.1(116.8-133.8)$ & $108.0(101.0-114.9)$ & $-17.1(-18.5--15.6)$ & -0.14 \\
\hline Asia & S.E. Asia & 185.0 & $40.2(34.0-46.9)$ & $39.2(33.7-45.9)$ & $-1.0(-1.1--0.8)$ & -0.02 \\
\hline Australia & N. Australia & 105.1 & $30.1(26.1-34.0)$ & $23.9(20.7-27.0)$ & $-6.1(-7.0--5.2)$ & -0.20 \\
\hline Total & & 1667.5 & $320.5(282.4-358.6)$ & $285.1(251.8-318.9)$ & $-35.2(-39.4--30.7)$ & -0.13 \\
\hline
\end{tabular}

* Tree height estimated from region-specific Weibull- $H$ models adapted from the pantropical tree $H: D$ database of Feldpausch et al. (2011). Region geographic extent is shown in Fig. 1. Tropical forest area was estimated for each region based on the broadleaf deciduous open and closed and evergreen tree cover classification from GLC2000 (Global Land Cover Map 2000) (Bartholomé and Belward, 2005).

differences in maximum heights among continents. Intriguingly, the biomass distribution by diameter class appear to follow a continental split, not a forest stature split, with the Guiana Shield forests grouping with the rest of South America and not African forests. The reasons for this are unclear, but may be related to the interaction between stem density and $H$. These studies showed that $H: D$ relationships were related to stem density, with forests with higher stem density having shorter trees for a given diameter. Trees of the Guiana Shield, for example, have the lowest stem density for plots in South America, and also are on average taller and have the highest biomass stocks for the continent (Table 4; Supplement Table S2). Our current results indicate that the inclusion of $H$ in biomass estimates for the Guiana Shield, Asia and Central Africa forests, with trees on average taller for a given $D$, does not substantially modify estimates compared to estimates based on the no- $H$ Eq. (1), but that including $H$ in biomass estimates for those regions reduces the bias in destructive estimates relative to excluding $H$ (Table 2). These results showing substantial variation in biomass distribution and forest structure among regions and continents indicate that future biomass models based on continents and regions may prove more robust than pantropical models.

\subsubsection{Climate and biogeography}

Furthermore, the patterns that emerge in tree $H$ variation as a function of region, climate, and forest structure suggest alternative structuring is needed for pantropical Biomass:Diameter tree allometric models rather than basing them solely on forest moisture class (e.g., dry, moist, wet). For example, $H: D$ relationships vary not only according to climate (e.g. taller trees in moist climates), but also by forest structure (e.g. taller trees in higher basal area forests), soil quality, and geography (e.g. taller trees for a given diameter in the Guyana Shield, Africa and Asia than in the rest of South America and Australia; Feldpausch et al., 2011). Biomass:Diameter allometry for most published large-scale biomass models, however, is fixed by region (e.g., Amazonia, Chambers et al., 2001) or is pantropical (e.g., Chave et al., 2005), or is based on broad classifications of forest moisture (e.g., dry, moist, or wet forest, Chave et al., 2005) or vegetation (e.g., diptercarp, secondary forest, Basuki et al., 2009; Nelson et al., 1999). These models therefore lack parameters to account for possible climate-driven or biogeographic variation in Biomass:Diameter relationships. However, the clear biogeographical differences amongst SE Asian (dominated by the Dipterocarpaceae) and forests on other continents are not shown here, and were not the proximate reason for differences in $H: D$ allometry in Asia versus elsewhere (Banin et al., 2012). Formation of region-specific $H$ models provides a first step in parameterising regional biomass estimates based 
on reported variation in tree $H$ allometry (Nogueira et al., 2008b; Feldpausch et al., 2011).

Current pantropical biomass models are also unable to account for regional or forest-specific variation in crown diameter, where wider crowns may impart greater biomass for a given diameter. Based on high-resolution remote sensing data, Barbier et al. (2010) indicated that crown size increases by $\sim 20 \%$ from the wetter to the more-seasonal regions of Amazonia. The regional $H$ patterns showing shorter trees in Southern Amazonia (Nogueira et al., 2008b; Feldpausch et al., 2011) that would result in reduced biomass stocks, may be partially offset by wider crowns that contain more mass for a given diameter. Such possible effects remain to be tested with field data.

\subsubsection{Intra-species, diameter-specific and regional wood density variation}

Tree wood specific gravity $\left(\rho_{\mathrm{W}}\right)$ variation is another parameter that biomass models may inadequately represent. This is because wood specific gravity (1) is highly variable across regions (2) is a key determinant of large-scale tree biomass spatial patterns (Baker et al., 2004b; Chave et al., 2006) and (3) is a more important predictor than tree height in biomass models (Chave et al., 2005). Therefore, accounting for it holds a central role in reducing uncertainty in biomass estimates. Current biomass calculations use $\rho_{\mathrm{W}}$ databases to assign the finest taxonomic value to an individual (e.g., speciesspecific $\left.\rho_{\mathrm{W}}\right)$ independent of stem diameter, and our bootstrapped estimates account for uncertainty in $\rho_{\mathrm{W}}$ (in addition to $H$ ). Data from Barro Colorado Island, Panama, showed significantly lower $\rho_{\mathrm{W}}$ in large-diameter trees than in smaller trees (Chave et al., 2004), while Patiño et al. (2009) showed, using branch wood density (which may be more plastic than stem wood density), that there is considerable plot-to-plot variation in wood specific gravity for a given species. Additionally, mean tree $\rho_{\mathrm{W}}$ is significantly lower in some regions of Amazonia (Nogueira et al., 2007). In addition, engineering theory suggests that trees with low density wood have an advantage in both $H$ growth and in mechanical stability as compared to high wood density trees (Anten and Schieving, 2010; Iida et al., 2012); in contrast to vertical growth, high density wood imparts greater efficiency for horizontal expansion. Together, these results suggest that biomass models may benefit from greater parameterisation.

Variation in the wood carbon fraction is another source of uncertainty in estimating regional and pantropical carbon stocks. Many studies, as in the current study, take the wood carbon fraction as 0.5 to convert estimated biomass to carbon (e.g., Lewis et al., 2009; Malhi et al., 2004; Clark et al., 2001). However, carbon content varies regionally (Elias and Potvin, 2003), where, for example, a forest in Panama has mean carbon values of $0.474 \pm 0.025$, which would result in an overestimate of $4.1-6.8 \mathrm{MgC} \mathrm{ha}^{-1}$ if the assumed 0.5 carbon content were used (Martin and Thomas, 2011).
Accounting for such variation may assist in refining future pantropical carbon estimates.

\subsubsection{Limited spatial extent}

A further concern is the use of spatially limited, destructively sampled biomass data forming the base of biomass models used to estimate biomass for trees in other regions. Until only recently, destructive data were unavailable for Africa, so that large-scale biomass estimates for this continent were based on data from elsewhere. Regional biomass equations may yield site-specific bias. For example, the Chambers et al. (2001) equation, which is based on data from a small area north of Manaus, Brazil, yet by necessity has been used to estimate biomass across the Amazon Basin (Baker et al., 2004a; Malhi et al., 2004, 2006), an area with important variation in tree architecture (Nogueira et al., 2008b; Feldpausch et al., 2011; Barbier et al., 2010), taxonomy (Pitman et al., 1999), and wood density (Baker et al., 2004b). Application of this model to Southern Amazonia requires a height factor to down-scale biomass estimates to account for shorter trees (Nogueira et al., 2008b, 2007). Country-level assessments of biomass model effects on estimates indicate that application of generic pantropical biomass models (e.g., Brown et al., 1989; Chave et al., 2005) should be evaluated prior to application, especially those that lack $H$ parameterisation (Alvarez et al., 2012; Vieilledent et al., 2012; Marshall et al., 2012). Our current results showed tropics-wide geographical variation in biomass distribution among $D$ classes in permanent plots, which, together with tropics-wide variation in $H: D$ relationships (Feldpausch et al., 2011), may not be represented when forming small regional subsets or pooling pantropical destructive data without accounting for $H$.

\subsection{Consequences for remote sensing}

Observed tropical forest $H: D$ allometry differences in ground-based studies (Feldpausch et al., 2011; Nogueira et al., 2008b; Banin et al., 2012) and their associated regional effects on biomass estimates shown here will be important for improving retrieval of biomass estimates from LiDAR (e.g., Drake et al., 2002; Lefsky et al., 2005; Asner et al., 2010) and radar (Geoscience Laser Altimeter System, GLAS; e.g., Saatchi et al., 2011) techniques that estimate a canopy $H$, or are used to estimate forest structure (full waveform LiDAR), either of which is then translated into a biomass estimate. Current pantropical remote sensing biomass estimates (e.g., Saatchi et al., 2011) transform remotely-sensed estimates of canopy height into biomass estimates based on the relationship between basalarea weighted $H$ (Lorey's $H$ ) for a ground-based plot and biomass estimates for trees within those plots, or based on the relationship between carbon density estimated from allometric models (e.g., Chave et al., 2005) and remotelysensed estimates of canopy height (e.g., Baccini et al., 2012). 
Minimising error in estimating biomass for trees within plots will likewise reduce error when calibrating remotely sensed estimates of biomass via LiDAR or radar. Height inclusion in the allometry used to estimate biomass for those plots reduces uncertainty, as we have shown here. Future remote sensing biomass estimates that address regional variations in $H$ and its effect on biomass estimates when calibrating remotely sensed $H$ to estimate biomass should therefore assist in evaluating potential bias and be able to provide tropical biomass estimates of improved accuracy.

\subsection{Implications for carbon sink and estimates of nutrient turnover}

Permanent plot data indicate that intact apparently mature tropical forests are not in biomass equilibrium, but have tended to gain biomass per unit area. Tree recruitment has outpaced mortality (Phillips et al., 2004) and total tree aboveground biomass has increased over recent decades (Phillips et al., 1998, 2009; Lewis et al., 2009). It has been estimated that, on average, trees in tropical forests add $0.49 \mathrm{Mg} \mathrm{Cha}^{-1}$ in aboveground mass each year, implying a carbon sink in aboveground live biomass of $0.9 \mathrm{PgC} \mathrm{yr}^{-1}$ (Lewis et al., 2009). This process, however, is susceptible to drought, and for Amazonia the 2005 drought at least temporarily reduced the long-term aboveground carbon sequestration (Phillips et al., 2009).

Our lower mean biomass estimates from forest plots implies that the calculated net carbon sink or the magnitude of any reversal or reduction in the sink due to drought may also be reduced for some regions as a direct result of $H$ parameterisations using current pantropical biomass models (but see Sect. 4.5). This assumes that the proportional sink remains unchanged. Furthermore, biomass estimates for individual trees are frequently used to estimate nutrient stocks such as nitrogen and phosphorus in trees and stands (Feldpausch et al., 2004, 2010; Buschbacher et al., 1988) based on component tissue concentrations (Martinelli et al., 2000). Reducing biomass estimates due to $H$ will therefore reduce the total estimated aboveground nutrient stocks and flux due to land-use change (e.g., selective logging, deforestation, forest regrowth and fire).

\subsection{Comparison with global emissions}

The biomass and carbon reduction due to $H$ also affects estimates of carbon emissions. The recent Intergovernmental Panel on Climate Change (IPCC) estimate of global emissions contribution of tropical deforestation estimates a net annual emission from this source of $1.6 \mathrm{PgC}$ (range 1.0 2.2 Pg C) (Denman et al., 2007) based on the mean of estimates by DeFries et al. (2002) and Houghton (2003) from the 1980s and 1990s. The recent "unofficial" estimate with the same methodology is $1.47 \mathrm{Pg} \mathrm{C} \mathrm{yr}^{-1}$ for the $2000-2005$ period (Houghton, 2008). Our new results incorporating $H$ into these estimates imply that this is an overestimate of $\sim 0.11 \mathrm{Pg} \mathrm{Cyr}^{-1}$, this being based on the more recent number for the values used in the estimate for emissions from belowground biomass and uptake of secondary forest regeneration, the contribution of live aboveground biomass cut in tropical deforestation of $0.85 \mathrm{Pg} \mathrm{C} \mathrm{yr}^{-1}$, and a 0.13 downward adjustment for tree $H$ (Table 5). For comparison, the last national inventory of the UK under Climate Convention indicates a total emission in 2007 of $0.17 \mathrm{Pg} \mathrm{yr}^{-1}$ of $\mathrm{CO}_{2}$-equivalent carbon (UK Department of Energy and Climate Change, 2009).

\subsection{Repercussions for carbon estimation and REDD+}

Integration of $H$ into biomass estimates reduces estimates of tropical carbon storage by $13 \%$. This estimated decrease has potential economic implications based on the calculated high carbon storage of pantropical forests under Reducing Emissions from Deforestation and Degradation (REDD+) carbonpayment schemes (Miles and Kapos, 2008). In monetary terms, our calculated decrease in carbon storage represents a reduction in value, in some regions, per unit area of tropical forests based on current carbon market prices (e.g., Chicago Climate Exchange, European Climate Exchange) if previous estimates utilised published pantropical allometry and excluded $H$ measurements. However, we stress (1) the actual carbon storage of these forests has not changed, only the estimated amount; (2) the large-scale RAINFOR South American estimates of biomass and change (e.g., Malhi et al., 2006; Phillips et al., 2009) used the Baker et al. (2004b) regional biomass model; for Africa, Weibull asymptotic continentalscale $H$ equations were used to estimate height in the Chave et al. (2005) pantropical allometric equations (Lewis et al., 2009); hence, the effect of accounting for $H$ in their estimates remains unexplored; (3) that our adjustments in plot-based estimates are sensitive to the current pantropical biomass equations as discussed above; future improvement and inclusion of additional data (e.g., from Africa) and harvested trees of larger diameter will further reduce uncertainty in estimates over a heterogeneous landscape and at a variety of scales; new models may eventually show that such downscaling is unnecessary; (4) tree $H$ integration can reduce uncertainty in biomass estimates (Figs. 2 b and 4 ), which should benefit REDD+ carbon accounting; (5) our extrapolations to regions and the tropics are based on necessarily limited sample sizes. Furthermore, the Tier 1 estimation method of forest carbon density issued in support of REDD+ by IPCC is based on average carbon values for biomes (IPCC, 2006), not plot-based estimates. The approach outlined in the present study, coupled with better measurement of $H$ (e.g., using LiDAR), can help generate accurate, verifiable biomass estimates which will ultimately increase confidence in largescale carbon estimates, potentially increasing the area receiving carbon credits, and greater investment per unit of carbon (Asner et al., 2010). 


\section{Conclusions and future considerations}

Based on these results, it is possible to make a number of recommendations:

1. A major initiative is needed to expand the pantropical destructive tree data to support global carbon modelling and policy; additional sampling is needed from under-represented regions, forest types, growth forms (e.g., palms), and tree diameter classes to represent the full diversity of tropical forests. We showed distinct differences in the biomass distribution among diameter classes of tropical forests in different regions across the tropics, and such apparently important differences will only be fully accounted for in biomass estimates when we have improved understanding through destructive sampling.

2. Pantropical permanent forest plots, some monitored since the 1970s, are now a baseline standard by which scientists and policymakers understand forest dynamics and potential changes in net carbon gain, with implications for carbon valuation under REDD+. There is known large variation in $H$ among these plots. To account for this variation and make full use of permanentplot data, we recommend a stratified random sample of $H$ measurements. If possible, $H$ measurements of every tree are desirable. Where local $H$-diameter relationships are not known, using those described in this paper is recommended.

Biomass estimates of tropical forests are prone to error because of the very small destructive dataset, biomass models, $H$ models and also because of uncertainty in unambiguously defining an area of tropical forest. Our study has explored the uncertainty associated with current biomass estimates and has shown the importance of accounting for treelevel variation in $H: D$ relationships for scaling to more precise regional and global biomass estimates. By reducing uncertainty in pantropical estimates, we make a step forward in providing realistic, verifiable carbon estimates for models and policy instruments such as REDD+.

\section{Supplementary material related to this article is available online at: http://www.biogeosciences.net/9/ 3381/2012/bg-9-3381-2012-supplement.pdf.}

Acknowledgements. Research was undertaken with the RAINFOR and AfriTRON networks with support in particular from the Gordon and Betty Moore Foundation and NERC through the AMAZONICA, TROBIT, and AfriTRON projects. LB was supported by a NERC PhD Studentship and Henrietta Hutton Grant (RGS-IBG). OP is supported by a European Research Council Advanced Grant. SLL is supported by a Royal Society University Research Fellowship; some African data were collected under a
NERC New Investigator Award (AfriTRON). TRF and MG are partially supported by NERC AMAZONICA. Additional support was provided by EScFund grant of the Malaysian Ministry of Science, Technology and Innovation (MOSTI); Tropenbos International and the European Commission; Large-scale Biosphere Atmosphere Experiment in Amazonia (LBA) under the leadership of the Brazilian Ministry of Science and Technology (MCT); PELD-CNPq (Proc. Nr. 558069/2009-6) and PROCAD-CAPES; the Brazilian National Council for Scientific and Technological Development (CNPq), and the Tropical Ecology Assessment and Monitoring (TEAM) Network, a collaboration between Conservation International, the Missouri Botanical Garden, the Smithsonian Institution, and the Wildlife Conservation Society, and partially funded by these institutions, the Gordon and Betty Moore Foundation, and other donors. For provision of, or help in collecting data, we thank A. W. Graham, M. G. Bradford, A. Ford, D. Wilson, K. Davies, M. Johnson, J. Grace, P. Meir, CSIRO and the Australian Canopy Crane Research Station, James Cook University (Australia), E. Chavez, A. Sota, M. Steininger, J. S. Taborga, (Bolivia); Rohden Indústria Lignea Ltda, J. Barroso, W. Castro, E. Couto, C. A. Passos (deceased), P. Nunes, D. Sasaki, D. M. de Freitas, M. Keller, G. B. da S. Oliveira, I. O. V. C. Feldpausch, L. Maracahipes, E. A. Oliveira, H. A. Mews, D. V. Silvério, M. Palace, M. Hunter, M. Keller, Instituto de Pesquisa da Amazônia (IPAM), Woods Hole Research Center (WHRC) and Grupo Amaggi at Fazenda Tanguro (Brazil); Guyana Forestry Commission, Iwokrama International Centre for Rainforest Conservation and Development, M. Drescher (Guyana); J. H. Ovalle, M. M. Solórzano (Peru); R. Sukri, M. Salleh A. B. (Brunei); D. Burslem, C. Maycock (Sabah); L. Chong, S. Davies, R. Shutine, L. K. Kho (Sarawak); for logistical aid and maintenance of the large scale forest dynamics plots at Pasoh Forest Reserve, Malaysia and Lambir Hills National Park, Sarawak, Malaysia, we thank, respectively, the Forest Research Institute Malaysia (FRIM) and the Sarawak Forestry Corporation, Malaysia, the Center for Tropical Forest Science - Arnold Arboretum Asia Program of the Smithsonian Tropical Research Institute and Harvard University, USA and Osaka City University, Japan and their funding agencies; V. O. Sene, J. Sonké, K. C. Nguembou; M.-N. Djuikouo K., R. Fotso and Wildlife Conservation Society, Cameroon, ECOFAC-Cameroon, Cameroon Ministry Scientific Research and Innovation, Cameroon Ministry of Forests and Fauna (MINFOF; Cameroon); A. Moungazi, S. Mbadinga, H. Bourobou, L. N. Banak, T. Nzebi, K. Jeffery, SEGC/CIRMF/WCS Research Station Lopé (Gabon); K. Ntim, K. Opoku, Forestry Commission of Ghana (Ghana); A. K. Daniels, S. Chinekei, J. T. Woods, J. Poker, L. Poorter, Forest Development Authority (Liberia), Valuing the Arc Program, Leverhulme Trust, N. Burgess, A. Balmford, A.R. Marshall, P. K. T. Munishi (Tanzania). This research benefitted from the enthusiastic help of many field assistants from across Africa, Asia, Australia, and South America.

Edited by: P. Stoy 


\section{References}

Akaike, H.: A new look at the statistical model identification, IEEE Trans. Autom. Contr., 19, 716-723, 1974.

Alvarez, E., Duque, A., Saldarriaga, J., Cabrera, K., de las Salas, G., del Valle, I., Lema, A., Moreno, F., Orrego, S., and Rodríguez, L.: Tree above-ground biomass allometries for carbon stocks estimation in the natural forests of Colombia, For. Ecol. Manage., 267, 297-308, doi:10.1016/j.foreco.2011.12.013, 2012.

Anten, N. P. and Schieving, F.: The role of wood mass density and mechanical constraints in the economy of tree architecture, Am. Nat., 175, 250-260, doi:10.1086/649581, 2010.

Aragao, L. E. and Shimabukuro, Y. E.: The incidence of fire in Amazonian forests with implications for REDD, Science, 328, 12751278, doi:10.1126/science.1186925, 2010.

Araújo, T. M., Higuchi, N., and Andrade de Carvalho Júnior, J.: Comparison of formulae for biomass content determination in a tropical rain forest site in the state of Pará, Brazil, For. Ecol. Manage., 117, 43-52, 1999.

Asner, G. P., Powell, G. V. N., Mascaro, J., Knapp, D. E., Clark, J. K., Jacobson, J., Kennedy-Bowdoin, T., Balaji, A., PaezAcosta, G., Victoria, E., Secada, L., Valqui, M., and Hughes, R. F.: High-resolution forest carbon stocks and emissions in the Amazon, Proc. Natl. Acad. Sci. USA, 107, 16738-16742, doi:10.1073/pnas.1004875107, 2010.

Baccini, A., Goetz, S. J., Walker, W. S., Laporte, N. T., Sun, M., Sulla-Menashe, D., Hackler, J., Beck, P. S. A., Dubayah, R., Friedl, M. A., Samanta, S., and Houghton, R. A.: Estimated carbon dioxide emissions from tropical deforestation improved by carbon-density maps, Nature Clim. Change, 2, 182-185, available at: http://www.nature.com/nclimate/journal/v2/n3/abs/ nclimate1354.html\#supplementary-information, 2012.

Bailey, R. L.: The potential of Weibull-type functions as flexible growth curves: discussion, Can. J. For. Res., 10, 117-118, 1979.

Baker, T. R., Phillips, O. L., Malhi, Y., Almeida, S., Arroyo, L., Di Fiore, A., Erwin, T., Higuchi, N., Killeen, T. J., Laurance, S. G., Laurance, W. F., Lewis, S. L., Monteagudo, A., Neill, D. A., Vargas, P. N., Pitman, N. C., Silva, J. N., and Martinez, R. V.: Increasing biomass in Amazonian forest plots, Philos. Trans. R. Soc. Lond. B Biol. Sci., 359, 353-365, doi:10.1098/rstb.2003.1422, 2004a.

Baker, T. R., Phillips, O. L., Malhi, Y., Almeida, S., Arroyo, L., Di Fiore, A., Erwin, T., Killeen, T. J., Laurance, S. G., Laurance, W. F., Lewis, S. L., Lloyd, J., Monteagudo, A., Neill, D. A., Patino, S., Pitman, N. C. A., Silva, J. N. M., and Martinez, R. V.: Variation in wood density determines spatial patterns in Amazonian forest biomass, Global Change Biol., 10, 545-562, doi:10.1111/j.1529- 8817.2003.00751.x, 2004b.

Baker, T. R., Phillips, O. L., Laurance, W. F., Pitman, N. C. A., Almeida, S., Arroyo, L., DiFiore, A., Erwin, T., Higuchi, N., Killeen, T. J., Laurance, S. G., Nascimento, H., Monteagudo, A., Neill, D. A., Silva, J. N. M., Malhi, Y., López Gonzalez, G., Peacock, J., Quesada, C. A., Lewis, S. L., and Lloyd, J.: Do species traits determine patterns of wood production in Amazonian forests?, Biogeosciences, 6, 297-307, doi:10.5194/bg-6297-2009, 2009.

Banin, L.: Cross-continental comparisons of tropical forest structure and function, $\mathrm{PhD}$, School of Geography, PhD Thesis, University of Leeds, Leeds, UK, 2010.
Banin, L., Feldpausch, T. R., Phillips, O. L., Baker, T. R., Lloyd, J., Affum-Baffoe, K., Arets, E. J. M. M., Berry, N. J., Bradford, M., Breinen, R. J. W., Davies, S., Drescher, M., Higuchi, N., Hilbert, D., Hladik, A., Iida, Y., Silam, K. A., Kassim, A. R., King, D. A., Lopez-Gonzalez, G., Metcalfe, D., Nilus, R., Peh, K. S.-H., Reitsma, J. M., Sonké, B., Taedoumg, H., Tan, S., White, L., Wöll, H., and Lewis, S. L.: What controls forest architecture? Testing environmental, structural and floristic drivers, Global Ecol. Biogeogr., in press, doi:10.1111/j.1466-8238.2012.00778.x, 2012.

Barbier, N., Couteron, P., Proisy, C., Malhi, Y., and GastelluEtchegorry, J. P.: The variation of apparent crown size and canopy heterogeneity across lowland Amazonian forests, Global Ecol. Biogeogr., 19, 72-84, doi:10.1111/j.14668238.2009.00493.x, 2010.

Bartholomé, E. and Belward, A. S.: GLC2000: a new approach to global land cover mapping from Earth observation data, Int. J. Remote Sens., 26, 1959-1977, 2005.

Baskerville, G.: Use of logarithmic regression in the estimation of plant biomass, Can. J. For. Res., 2, 49-53, 1972.

Basuki, T. M., van Laake, P. E., Skidmore, A. K., and Hussin, Y. A.: Allometric equations for estimating the above-ground biomass in tropical lowland Dipterocarp forests, For. Ecol. Manage., 257, 1684-1694, doi:10.1016/j.foreco.2009.01.027, 2009.

Brown, I. F., Martinelli, L. A., Thomas, W. W., Moreira, M. Z., Ferreira, C. A. C., and Victoria, R. A.: Uncertainty in the biomass of Amazonian forests: an example from Rondonia, Brazil, For. Ecol. Manage., 75, 175-189, 1995.

Brown, S.: Estimating biomass and biomass change of tropical forests: a primer, FAO Forestry Paper, 134, 1997.

Brown, S., Gillespie, A. J. R., and Lugo, A. E.: Biomass estimation methods for tropical forests with applications to forestry inventory data, For. Sci., 35, 881-902, 1989.

Buschbacher, R., Uhl, C., and Serrão, E. A. S.: Abandoned pastures in eastern Amazonia. II. Nutrient stocks in the soil and vegetation, J. Ecol., 76, 682-699, 1988.

Chambers, J. Q., dos Santos, J., Ribeiro, R. J., and Higuchi, N.: Tree damage, allometric relationships, and above-ground net primary production in central Amazon forest, For. Ecol. Manage., 152, 73-84, 2001.

Chave, J., Condit, R., Lao, S., Caspersen, J. P., Foster, R. B., and Hubbell, S. P.: Spatial and temporal variation of biomass in a tropical forest: results from a large census plot in Panama, J. Ecol., 91, 240-252, 2003.

Chave, J., Condit, R., Aguilar, S., Hernandez, A., Lao, S., and Perez, R.: Error propagation and scaling for tropical forest biomass estimates, Philos. Trans. R. Soc. Lond. B Biol. Sci., 359, 409-420, doi:10.1098/rstb.2003.1425, 2004.

Chave, J., Andalo, C., Brown, S., Cairns, M. A., Chambers, J. Q., Eamus, D., Folster, H., Fromard, F., Higuchi, N., Kira, T., Lescure, J. P., Nelson, B. W., Ogawa, H., Puig, H., Riera, B., and Yamakura, T.: Tree allometry and improved estimation of carbon stocks and balance in tropical forests, Oecologia, 145, 87-99, doi:10.1007/s00442- 005-0100-x, 2005.

Chave, J., Muller-Landau, H. C., Baker, T. R., Easdale, T. A., ter Steege, H., and Webb, C. O.: Regional and phylogenetic variation of wood density across 2456 Neotropical tree species, Ecol. Appl., 16, 2356-2367, 2006. 
Chave, J., Coomes, D., Jansen, S., Lewis, S. L., Swenson, N. G., and Zanne, A. E.: Towards a worldwide wood economics spectrum, Ecol. Lett., 12, 351-366, doi:10.1111/j.14610248.2009.01285.x, 2009.

Clark, D. A., Brown, S., Kicklighter, D. W., Chambers, J. Q., Thomlinson, J. R., and Ni, J.: Measuring net primary production in forests: concepts and field methods, Ecol. Appl., 11, 356-370, 2001.

Crow, T. R.: Notes: common regressions to estimate tree biomass in tropical stands, For. Sci., 24, 110-114, 1978.

Davies, S. J., Palmiotto, P. A., Ashton, P. S., Lee, H. S., and Lafrankie, J. V.: Comparative ecology of 11 sympatric species of Macaranga in Borneo: tree distribution in relation to horizontal and vertical resource heterogeneity, J. Ecol., 86, 662-673, 1998.

Deans, J. D., Moran, J., and Grace, J.: Biomass relationships for tree species in regenerating semi-deciduous tropical moist forest in Cameroon, For. Ecol. Manage., 88, 215-225, 1996.

DeFries, R. S., Houghton, R. A., Hansen, M. C., Field, C. B., Skole, D., and Townshend, J.: Carbon emissions from tropical deforestation and regrowth based on satellite observations for the 1980s and 1990s, Proc. Natl. Acad. Sci., 99, 14256-14261, doi:10.1073/pnas.182560099, 2002.

Denman, K., Brasseur, G., Chidthaisong, A., Ciais, P., Cox, P., Dickinson, R., Hauglustaine, D., Heinze, C., Holland, E., Jacob, D., Lohmann, U., Ramachandran, S., Pedro Leite da Silva, D., Wofsy, S., and Zhang, X.: Couplings between changes in the climate system and biogeochemistry, in: Climate Change 2007: The Physical Science Basis, Contribution of Working Group I to the Fourth Assessment Report of the Intergovernmental Panel on Climate Change, edited by: Solomon, S., Qin, D., Manning, M., Chen, Z., Marquis, M., Averyt, K. B., Tignor, and Miller, H. L., Cambridge University Press, 499-587, 2007.

Djomo, A. N., Ibrahima, A., Saborowski, J., and Gravenhorst, G.: Allometric equations for biomass estimations in Cameroon and pan moist tropical equations including biomass data from Africa, For. Ecol. Manage., 260, 1873-1885, doi:10.1016/j.foreco.2010.08.034, 2010.

Drake, J. B., Dubayah, R. O., Clark, D. B., Knox, R. G., Blair, J. B., Hofton, M. A., Chazdon, R. L., Weishampel, J. F., and Prince, S. D.: Estimation of tropical forest structural characteristics using large-footprint lidar, Remote Sens. Environ., 79, 305-319, 2002.

Ebuy, J., Lokombe, J. P., Ponette, Q., Sonwa, D., and Picard, N.: Allometric equation for predicting aboveground biomass of three tree species, J. Trop. For. Sci., 23, 125-132, 2011.

Elias, M. and Potvin, C.: Assessing inter- and intra-specific variation in trunk carbon concentration for 32 neotropical tree species, Can. J. For. Res., 33, 1039-1045, 2003.

ESRI: ArcGIS Desktop: Release 10, Environmental Systems Research Institute, Redlands, CA, USA, available at: http://www. esri.com/ (last access: 13 August 2012), 2010.

Fang, Z. and Bailey, R. L.: Height-diameter models for tropical forests on Hainan Island in southern China, For. Ecol. Manage., 110, 315-327, 1998.

Fearnside, P. M.: Wood density for estimating forest biomass in Brazilian Amazonia, For. Ecol. Manage., 90, 59-87, 1997.

Feldpausch, T. R., Rondon, M. A., Fernandes, E. C. M., Riha, S. J., and Wandelli, E.: Carbon and nutrient accumulation in secondary forests regenerating on pastures in central Amazonia, Ecol. Appl., 14, S164-S176, doi:10.1890/01-6015, 2004.
Feldpausch, T. R., Jirka, S., Passos, C. A. M., Jasper, F., and Riha, S. J.: When big trees fall: damage and carbon export by reduced impact logging in southern Amazonia, For. Ecol. Manage., 219, 199-215, doi:10.1016/j.foreco.2005.09.003, 2005.

Feldpausch, T. R., Coutoz, E. G., Rodrigues, L. C., Pauletto, D., Johnson, M. S., Fahey, T. J., Lehmann, J., and Riha, S. J.: Nitrogen aboveground turnover and soil stocks to $8 \mathrm{~m}$ depth in primary and selectively logged forest in southern Amazonia, Global Change Biol., 16, 1793-1805, doi:10.1111/j.13652486.2009.02068.x, 2010.

Feldpausch, T. R., Banin, L., Phillips, O. L., Baker, T. R., Lewis, S. L., Quesada, C. A., Affum-Baffoe, K., Arets, E. J. M. M., Berry, N. J., Bird, M., Brondizio, E. S., de Camargo, P., Chave, J., Djagbletey, G., Domingues, T. F., Drescher, M., Fearnside, P. M., Franca, M. B., Fyllas, N. M., Lopez-Gonzalez, G., Hladik, A., Higuchi, N., Hunter, M. O., Iida, Y., Salim, K. A., Kassim, A. R., Keller, M., Kemp, J., King, D. A., Lovett, J. C., Marimon, B. S., Marimon, B. H., Lenza, E., Marshall, A. R., Metcalfe, D. J., Mitchard, E. T. A., Moran, E. F., Nelson, B. W., Nilus, R., Nogueira, E. M., Palace, M., Patiño, S., Peh, K. S. H., Raventos, M. T., Reitsma, J. M., Saiz, G., Schrodt, F., Sonké, B., Taedoumg, H. E., Tan, S., White, L., Wöll, H., and Lloyd, J.: Heightdiameter allometry of tropical forest trees, Biogeosciences, 8 , 1081-1106, doi:10.5194/bg-8- 1081-2011, 2011.

Fittkau, E. J.: Esboço de uma divisão ecolôgica da região amazônica, Proc. Symp. Biol. Trop. Amaz., Florencia y Leticia, 1969, 1363-1372, 1971.

Fittkau, E. J. and Klinge, H.: On biomass and trophic structure of the central Amazonian rain forest ecosystem, Biotropica, 5, 2$14,1973$.

Gibbs, H. K., Brown, S., Niles, J. O., and Foley, J. A.: Monitoring and estimating tropical forest carbon stocks: making REDD a reality, Environ. Res. Lett., 2, 1-13, 2007.

Graham, A. W.: The CSIRO rainforest permanent plots of North Queensland: site, structural, floristic and edaphic descriptions, available at: http://nla.gov.au/nla.cat-vn3708155, Rainforest CRC, James Cook University, Cairns, Australia, 227 pp., 2006.

Griscom, B. W. and Ashton, P. M. S.: A self-perpetuating bamboo disturbance cycle in a neotropical forest, J. Trop. Ecol., 22, 587597, doi:10.1017/S0266467406003361, 2006.

Henry, M., Besnard, A., Asante, W. A., Eshun, J., Adu-Bredu, S., Valentini, R., Bernoux, M., and Saint-Andre, L.: Wood density, phytomass variations within and among trees, and allometric equations in a tropical rainforest of Africa, For. Ecol. Manage., 260, 1375-1388, doi:10.1016/j.foreco.2010.07.040, 2010.

Hijmans, R. J., Cameron, S. E., Parra, J. L., Jones, P. G., and Jarvis, A.: Very high resolution interpolated climate surfaces for global land areas, Int. J. Climatol., 25, 1965-1978, 2005.

Houghton, R. A.: Revised estimates of the annual net flux of carbon to the atmosphere from changes in land use and land management 1850-2000, Tellus B, 55, 378-390, doi:10.1034/j.16000889.2003.01450.x, 2003.

Houghton, R. A.: Carbon flux to the atmosphere from land-use changes: 1850-2005, in: TRENDS: a compendium of data on global change, Carbon Dioxide Information Analysis Center, US Department of Energy, Oak Ridge, Tenn., USA, 2008. 
Houghton, R. A.: How well do we know the flux of $\mathrm{CO}_{2}$ from land-use change?, Tellus B, 62, 337-351, doi:10.1111/j.16000889.2010.00473.x, 2010.

Houghton, R. A., Skole, D. L., Nobre, C. A., Hackler, J. L., Lawrence, K. T., and Chomentowski, W. H.: Annual fluxes of carbon from deforestation and regrowth in the Brazilian Amazon, Nature, 403, 301-304, 2000.

Hozumi, K., Yoda, K., Kokawa, S., and Kira, T.: Production ecology of tropical rain forests in southwestern Cambodia. I. Plant biomass, Nature and Life in Southeast Asia, 6, 1-51, 1969.

Iida, Y., Kohyama, T. S., Kubo, T., Kassim, A. R., Poorter, L., Sterck, F., and Potts, M. D.: Tree architecture and life-history strategies across 200 co-occurring tropical tree species, Funct. Ecol., 25, 1260-1268, doi:10.1111/j.1365-2435.2011.01884.x, 2011.

Iida, Y., Poorter, L., Sterck, F. J., Kassim, A. R., Kubo, T., Potts, M. D., and Kohyama, T. S.: Wood density explains architectural differentiation across 145 co-occurring tropical tree species, Funct. Ecol., 26, 274-282, doi:10.1111/j.13652435.2011.01921.x, 2012.

INPE: Monitoramento da floresta Amazônica Brasileira por satélite 2009, available at: http://www.inpe.br (last access: $13 \mathrm{Au}-$ gust 2012), Instituto Nacional de Pesquisas Espaciais (INPE), São José dos Campos, Brazil, 2009.

IPCC: 2006 IPCC guidelines for national greenhouse gas inventories, Institute for Global Environmental Strategies, Hayama, Japan, 2006.

Kindermann, G., Obersteiner, M., Sohngen, B., Sathaye, J., Andrasko, K., Rametsteiner, E., Schlamadinger, B., Wunder, S., and Beach, R.: Global cost estimates of reducing carbon emissions through avoided deforestation, Proc. Natl. Acad. Sci. USA, 105, 10302-10307, doi:10.1073/pnas.0710616105, 2008.

Ketterings, Q. M., Coe, R., van Noordwijk, M., Ambagau, Y., and Palm, C. A.: Reducing uncertainty in the use of allometric biomass equations for predicting above-ground tree biomass in mixed secondary forests, For. Ecol. Manage., 146, 199-209, 2001.

Larjavaara, M. and Muller-Landau, H. C.: Measuring tree height in moist tropical forest: a quantitative comparison of two common field methods, in preparation, 2012.

Laurance, W. F. and Curran, T. J.: Impacts of wind disturbance on fragmented tropical forests: A review and synthesis, Austral Ecol., 33, 399-408, doi:10.1111/j.1442- 9993.2008.01895.x, 2008.

Lefsky, M. A., Harding, D. J., Keller, M., Cohen, W. B., Carabajal, C. C., Espirito-Santo, F. D. B., Hunter, M. O., and de Oliveira Jr., R.: Estimates of forest canopy height and aboveground biomass using ICESat, Geophys. Res. Lett., 32, 1-4, 2005.

Lescure, J.-P., Puig, H., Riéra, B., Leclerc, D., Beekman, A., and Bénéteau, A.: La phytomasse épigée d'une forêt dense en Guyane française, Acta Oecol., 4, 237-251, 1983.

Lewis, S. L., Lopez-Gonzalez, G., Sonke, B., Affum-Baffoe, K., Baker, T. R., Ojo, L. O., Phillips, O. L., Reitsma, J. M., White, L., Comiskey, J. A., Djuikouo, K. M., Ewango, C. E., Feldpausch, T. R., Hamilton, A. C., Gloor, M., Hart, T., Hladik, A., Lloyd, J., Lovett, J. C., Makana, J. R., Malhi, Y., Mbago, F. M., Ndangalasi, H. J., Peacock, J., Peh, K. S., Sheil, D., Sunderland, T., Swaine, M. D., Taplin, J., Taylor, D., Thomas, S. C., Votere, R., and Woll, H.: Increasing carbon storage in intact African tropical forests,
Nature, 457, 1003-1006, doi:10.1038/nature07771, 2009.

Lohman, D. J., de Bruyn, M., Page, T., von Kintelen, K., Hall, R., $\mathrm{Ng}$, P. K. L., and von Rintelen, T.: Biogeography of the IndoAustralian archipeligo, Ann. Rev. Ecol. Syst., 42, 205-206, 2011.

Lopez-Gonzalez, G., Lewis, S. L., Burkitt, M., and Phillips, O. L.: ForestPlots.net: a web application and research tool to manage and analyse tropical forest plot data, J. Veg. Sci., 22, 610-613, doi:10.1111/j.1654-1103.2011.01312.x, 2011.

Lucas, R. M., Honzak, M., Amaral, I. D., Curran, P. J., and Foody, G. M.: Forest regeneration on abandoned clearances in central Amazonia, Int. J. Remote Sens., 23, 965-988, 2002.

Mackensen, J., Tillery-Stevens, M., Klinge, R., and Fölster, H.: Site parameters, species composition, phytomass structure and element stores of a terra-firme forest in East-Amazonia, Brazil, Plant Ecol., 151, 101-119, 2000.

Malhi, Y. and Wright, J.: Spatial patterns and recent trends in the climate of tropical rainforest regions, Phil. Trans. R. Soc. Lond. B., 359, 311-329, 2004.

Malhi, Y., Baker, T. R., Phillips, O. L., Almeida, S., Alvarez, E., Arroyo, L., Chave, J., Czimczik, C. I., Di Fiore, A., Higuchi, N., Killeen, T. J., Laurance, S. G., Laurance, W. F., Lewis, S. L., Montoya, L. M. M., Monteagudo, A., Neill, D. A., Vargas, P. N., Patino, S., Pitman, N. C. A., Quesada, C. A., Salomao, R., Silva, J. N. M., Lezama, A. T., Martinez, R. V., Terborgh, J., Vinceti, B., and Lloyd, J.: The above-ground coarse wood productivity of 104 Neotropical forest plots, Global Change Biol., 10, 563-591, 2004.

Malhi, Y., Wood, D., Baker, T. R., Wright, J., Phillips, O. L., Cochrane, T., Meir, P., Chave, J., Almeida, S., Arroyo, L., Higuchi, N., Killeen, T. J., Laurance, S. G., Laurance, W. F., Lewis, S. L., Monteagudo, A., Neill, D. A., Vargas, P. N., Pitman, N. C. A., Quesada, C. A., Salomao, R., Silva, J. N. M., Lezama, A. T., Terborgh, J., Martinez, R. V., and Vinceti, B.: The regional variation of aboveground live biomass in old-growth Amazonian forests, Global Change Biol., 12, 1107-1138, 2006.

Marshall, A. R., Willcock, S., Platts, P. J., Lovett, J. C., Balmford, A., Burgess, N. D., Latham, J. E., Munishi, P. K.T., Salter, R., Shirima, D. D., and Lewis, S. L.: Measuring and modelling above-ground carbon and tree allometry along a tropical elevation gradient, Biol. Conserv., in press, doi:10.1016/j.biocon.2012.03.017, 2012.

Martin, A. R. and Thomas, S. C.: A reassessment of carbon content in tropical trees, PLoS ONE, 6, e23533, doi:10.1371/journal.pone.0023533, 2011.

Martinelli, L. A., Almeida, S., Brown, I. F., Moreira, M. Z., Victoria, R. L., Filoso, S., Ferreira, C. A. C., and Thomas, W. W.: Variation in nutrient distribution and potential nutrient losses by selective logging in a humid tropical forest of Rondonia, Brazil, Biotropica, 32, 597-613, 2000.

Mayaux, P., Holmgren, P., Achard, F., Eva, H., Stibig, H., and Branthomme, A.: Tropical forest cover change in the 1990s and options for future monitoring, Philos. Trans. R. Soc. B, 360, 373384, doi:10.1098/rstb.2004.1590, 2005.

Miles, L. and Kapos, V.: Reducing greenhouse gas emissions from deforestation and forest degradation: global land-use implications, Science, 320, 1454-1455, doi:10.1126/science.1155358, 2008. 
Mitchard, E. T. A., Saatchi, S. S., Woodhouse, I. H., Nangendo, G., Ribeiro, N. S., Williams, M., Ryan, C. M., Lewis, S. L., Feldpausch, T. R., and Meir, P.: Using satellite radar backscatter to predict above-ground woody biomass: a consistent relationship across four different African landscapes, Geophys. Res. Lett., 36, L23401, doi:10.1029/2009GL040692, 2009.

Mitchard, E. T. A., Saatchi, S. S., Lewis, S. L., Feldpausch, T. R., Woodhouse, I. H., Sonké, B., Rowland, C., and Meir, P.: Measuring biomass changes due to woody encroachment and deforestation/degradation in a forest-savanna boundary region of central Africa using multi-temporal L-band radar backscatter, Remote Sens. Environ., 115, 2861-2873, doi:10.1016/j.rse.2010.02.022, 2011.

Montgomery, R. A. and Chazdon, R. L.: Forest structure, canopy architecture, and light transmittance in tropical wet forests, Ecology, 82, 2707-2718, 2001.

Morel, A. C., Saatchi, S. S., Malhi, Y., Berry, N. J., Banin, L., Burslem, D., Nilus, R., and Ong, R. C.: Estimating aboveground biomass in forest and oil palm plantation in Sabah, Malaysian Borneo using ALOS PALSAR data, For. Ecol. Manage., 262, 1786-1798, doi:10.1016/j.foreco.2011.07.008, 2011.

Nelson, B. W., Mesquita, R., Pereira, J. L. G., de Souza, S. G. A., Batista, G. T., and Couto, L. B.: Allometric regressions for improved estimate of secondary forest biomass in the central Amazon, For. Ecol. Manage., 117, 149-167, 1999.

Nogueira, E. M., Fearnside, P. M., Nelson, B. W., and Franca, M. B.: Wood density in forests of Brazil's "arc of deforestation": implications for biomass and flux of carbon from landuse change in Amazonia, For. Ecol. Manage., 248, 119-135, doi:10.1016/j.foreco.2007.04.047, 2007.

Nogueira, E. M., Fearnside, P. M., Nelson, B. W., Barbosa, R. I., and Keizer, E. W. H.: Estimates of forest biomass in the Brazilian Amazon: new allometric equations and adjustments to biomass from wood-volume inventories, For. Ecol. Manage., 256, 18531867, 2008a.

Nogueira, E. M., Nelson, B. W., Fearnside, P. M., França, M. B., and Oliveira, Á. C. A. d.: Tree height in Brazil's 'arc of deforestation': Shorter trees in south and southwest Amazonia imply lower biomass, For. Ecol. Manage., 255, 2963-2972, 2008b.

Ogawa, H., Yoda, K., and Kira, T.: Comparative ecological studies on three main types of forest vegetation in Thailand: II. Plant biomass, Nature and Life in South East Asia, 4, 49-80, 1965.

Overman, J. P. M., Witte, H. J. L., and Saldarriaga, J. G.: Evaluation of regression models for above-ground biomass determination in Amazon rainforest, J. Trop. Ecol., 10, 207-218, 1994.

Patiño, S., Lloyd, J., Paiva, R., Baker, T. R., Quesada, C. A., Mercado, L. M., Schmerler, J., Schwarz, M., Santos, A. J. B., Aguilar, A., Czimczik, C. I., Gallo, J., Horna, V., Hoyos, E. J., Jimenez, E. M., Palomino, W., Peacock, J., Peña-Cruz, A., Sarmiento, C., Sota, A., Turriago, J. D., Villanueva, B., Vitzthum, P., Alvarez, E., Arroyo, L., Baraloto, C., Bonal, D., Chave, J., Costa, A. C. L., Herrera, R., Higuchi, N., Killeen, T., Leal, E., Luizão, F., Meir, P., Monteagudo, A., Neil, D., Núñez-Vargas, P., Peñuela, M. C., Pitman, N., Priante Filho, N., Prieto, A., Panfil, S. N., Rudas, A., Salomão, R., Silva, N., Silveira, M., Soares deAlmeida, S., Torres-Lezama, A., Vásquez-Martínez, R., Vieira, I., Malhi, Y., and Phillips, O. L.: Branch xylem density variations across the Amazon Basin, Biogeosciences, 6, 545-568, doi:10.5194/bg-6545-2009, 2009.
Peacock, J., Baker, T. R., Lewis, S. L., Lopez-Gonzalez, G., and Phillips, O. L.: The RAINFOR database: monitoring forest biomass and dynamics, J. Veg. Sci., 18, 535-542, 2007.

Phillips, O. L., Malhi, Y., Higuchi, N., Laurance, W. F., Núñez, P. V., Vásquez, R. M., Laurance, S. G., Ferreira, L. V., Stern, M., Brown, S., and Grace, J.: Changes in the carbon balance of tropical forests: evidence from long-term plots, Science, 282, 439442, 1998.

Phillips, O. L., Baker, T. R., Arroyo, L., Higuchi, N., Killeen, T. J., Laurance, W. F., Lewis, S. L., Lloyd, J., Malhi, Y., Monteagudo, A., Neill, D. A., Vargas, P. N., Silva, J. N. M., Terborgh, J., Martinez, R. V., Alexiades, M., Almeida, S., Brown, S., Chave, J., Comiskey, J. A., Czimczik, C. I., Di Fiore, A., Erwin, T., Kuebler, C., Laurance, S. G., Nascimento, H. E. M., Olivier, J., Palacios, W., Patiño, S., Pitman, N. C. A., Quesada, C. A., Salidas, M., Lezama, A. T., and Vinceti, B.: Pattern and process in Amazon tree turnover, 1976-2001, Phil. Trans. Roy. Soc. Lnd. S. B-Bio Sci., 359, 381-407, 2004.

Phillips, O. L., Aragao, L. E., Lewis, S. L., Fisher, J. B., Lloyd, J., Lopez-Gonzalez, G., Malhi, Y., Monteagudo, A., Peacock, J., Quesada, C. A., van der Heijden, G., Almeida, S., Amaral, I., Arroyo, L., Aymard, G., Baker, T. R., Banki, O., Blanc, L., Bonal, D., Brando, P., Chave, J., de Oliveira, A. C., Cardozo, N. D., Czimczik, C. I., Feldpausch, T. R., Freitas, M. A., Gloor, E., Higuchi, N., Jimenez, E., Lloyd, G., Meir, P., Mendoza, C., Morel, A., Neill, D. A., Nepstad, D., Patiño, S., Penuela, M. C., Prieto, A., Ramirez, F., Schwarz, M., Silva, J., Silveira, M., Thomas, A. S., Steege, H. T., Stropp, J., Vásquez, R., Zelazowski, P., Alvarez Davila, E., Andelman, S., Andrade, A., Chao, K. J., Erwin, T., Di Fiore, A., Honorio, C. E., Keeling, H., Killeen, T. J., Laurance, W. F., Pena Cruz, A., Pitman, N. C., Núñez Vargas, P., Ramirez-Angulo, H., Rudas, A., Salamao, R., Silva, N., Terborgh, J., and Torres-Lezama, A.: Drought sensitivity of the Amazon rainforest, Science, 323, 1344-1347, doi:10.1126/science.1164033, 2009.

Phillips, O. L., Baker, T. R., Brienen, R., and Feldpausch, T. R.: Field manual for plot establishment and remeasurement, available at: http://www.geog.leeds.ac.uk/projects/rainfor/ (last access: February 2012), 2010.

Pinard, M. A. and Putz, F. E.: Retaining forest biomass by reducing logging damage, Biotropica, 28, 278-295, 1996.

Pinheiro, J. C., Bates, D. M., and Lindstrom, M. J.: Model building in nonlinear mixed effects models. Department of Statistics, Technical Report 931, University of Wisconsin, Madison, 1994.

Pinheiro, J., Bates, D., DebRoy, S., Sarkar, D., and the R Development Core Team: nlme: Linear and nonlinear mixed effects models, R package version 3.1-102, 2011.

Pitman, N. C. A., Terborgh, J., Silman, M. R., and Núñez, P.: Tree species distributions in an upper Amazonian forest, Ecology, 80, 2651-2661, 1999.

Poorter, L., Bongers, L., and Bongers, F.: Architecture of 54 moistforest tree species: Traits, trade-offs, and functional groups, Ecology, 87, 1289-1301, 2006.

Quesada, C. A., Phillips, O. L., Schwarz, M., Czimczik, C. I., Baker, T. R., Patiño, S., Fyllas, N. M., Hodnett, M. G., Herrera, R., Almeida, S., Alvarez Dávila, E., Arneth, A., Arroyo, L., Chao, K. J., Dezzeo, N., Erwin, T., di Fiore, A., Higuchi, N., Honorio Coronado, E., Jimenez, E. M., Killeen, T., Lezama, A. T., Lloyd, G., López-González, G., Luizão, F. J., Malhi, Y., Monteagudo, 
A., Neill, D. A., Núñez Vargas, P., Paiva, R., Peacock, J., Peñuela, M. C., Peña Cruz, A., Pitman, N., Priante Filho, N., Prieto, A., Ramírez, H., Rudas, A., Salomão, R., Santos, A. J. B., Schmerler, J., Silva, N., Silveira, M., Vásquez, R., Vieira, I., Terborgh, J., and Lloyd, J.: Basin-wide variations in Amazon forest structure and function are mediated by both soils and climate, Biogeosciences, 9, 2203-2246, doi:10.5194/bg-9-2203-2012, 2012.

R Development Core Team: R: A language and environment for statistical computing, R Foundation for Statistical Computing, available at: http://www.R-project.org (last access: $13 \mathrm{Au}-$ gust 2012), Vienna, Austria, 2011.

Rich, P. M., Helenurm, K., Kearns, D., Morse, S. R., Palmer, M. W., and Short, L.: Height and stem diameter relationships for dicotyledonous trees and arborescent palms of Costa Rican tropical wet forest, Bull. Torrey Bot. Club, 113, 241-246, 1986.

Saatchi, S. S., Houghton, R. A., Alvala, R., Soares, J. V., and Yu, Y.: Distribution of aboveground live biomass in the Amazon basin, Global Change Biol., 13, 816-837, 10.1111/j.13652486.2007.01323.x, 2007.

Saatchi, S. S., Harris, N. L., Brown, S., Lefsky, M., Mitchard, E. T., Salas, W., Zutta, B. R., Buermann, W., Lewis, S. L., Hagen, S., Petrova, S., White, L., Silman, M., and Morel, A.: Benchmark map of forest carbon stocks in tropical regions across three continents, Proc. Natl. Acad. Sci. USA, 108, 9899-9904, doi:10.1073/pnas.1019576108, 2011.

Samalca, I. K.: Estimation of forest biomass and its error: a case in Kalimantan, Indonesia, MSc., International Institute for Geoinformation Science and Earth Observation, The Netherlands, 74 pp., 2007.

Schargel, R.: Una reseña de la geografía física de Venezuela, con énfasis en los suelos, BioLlania Edición Esp., 10, 11-26, 2011.

Schargel, R., Marvez, P., Aymard, G., Stergios, B., and Berry, P.: Características de los suelos alrededor de San Carlos de Río Negro, Estado Amazonas, Venezuela, BioLlania Edic. Esp. No., 7, 234-264, 2001.

Schobbenhaus, C. and A. Bellizzia (coord.): Geological Map of South America, 1:5,000,000, CGMW- CPRM-DNPMUNESCO, Paris, 2001.

Shuttleworth, W. J.: Evaporation from Amazonian rainforest, Proc. Roy. Soc. Ldn. Ser. B. Biol. Sci., 233, 321-346, doi:10.1098/rspb.1988.0024, 1988.

Slik, J. W. F., Aiba, S.-I., Brearley, F. Q., Cannon, C. H., Forshed, O., Kitayama, K., Nagamasu, H., Nilus, R., Payne, J., Paoli, G., Poulsen, A. D., Raes, N., Sheil, D., Sidiyasa, K., Suzuki, E., and van Valkenburg, J. L. C. H.: Environmental correlates of tree biomass, basal area, wood specific gravity and stem density gradients in Borneo's tropical forests, Global Ecol. Biogeogr., 19, 50-60, doi:10.1111/j.1466-8238.2009.00489.x, 2010.

Sprugel, D.: Correcting for bias in log-transformed allometric equations, Ecology, 64, 209-210, 1983.
Steininger, M. K.: Satellite estimation of tropical secondary forest above-ground biomass: data from Brazil and Bolivia, Int. J. Remote Sens., 21, 1139-1157, 2000.

Thomas, S. C.: Asymptotic height as a predictor of growth and allometric characteristics in Malaysian rain forest trees, Am. J. Bot., 83, 556-566, 1996.

Thomas, S. C. and Bazzaz, F. A.: Asymptotic height as a predictor of photosynthetic characteristics in Malaysian forest trees, Ecology, 80, 1607-1622, 1999.

Torello-Raventosa, M., Feldpausch, T. R., Veenendaal, E., Schrodt, F., Saiz, G., Domingues, T. R., Djagbletey, G., Ford, A., Kemp, J., Marimon, B. S., Marimon Junior, B. H., Lenza, E., Ratter, J. A., Maracahipes, L., Sasaki, D., Sonké, B., Zapfack, L., Taedoumg, H., Villarroel, D., Schwarz, M., Quesada, C. A., Ishida, F. Y., Nardoto, G. B., Affum-Baffoe, K., Arroyo, L., Bowman, D. M. J. S., Compaore, H., Davies, K., Diallo, A., Fyllas, N. M., Gilpin, M., Hien, F., Johnson, M., Killeen, T. J., Metcalfe, D., Miranda, H. S., Steininger, M., Thomson, J., Sykora, K., Mougin, E., Hiernaux, P., Bird, M. I., Grace, J., Lewis, S. L., Phillips, O. L., and Lloyd, J.: On the delineation of tropical vegetation types with an emphasis on forest/savanna transitions, Plant Ecology and Diversity, in review, 2012.

Uhl, C. and Jordan, C. F.: Succession and nutrient dynamics following forest cutting and burning in Amazonia, Ecology, 65, 14761490, 1984.

UK Department of Energy and Climate Change: 5NC: The UK's Fifth National Communication under the United Nations Framework Convention on Climate Change, Department of Energy and Climate Change, London, UK, 153, 2009.

Vieilledent, G., Vaudry, R., Andriamanohisoa, S. F. D., Rakotonarivo, O. S., Randrianasolo, H. Z., Razafindrabe, H. N., Rakotoarivony, C. B., Ebeling, J., and Rasamoelina, M.: A universal approach to estimate biomass and carbon stock in tropical forests using generic allometric models, Ecol. Appl., 22, 572583, doi:10.1890/11-0039.1, 2012.

Watson, R. T., Noble, I. R., Bolin, B., Ravindranath, N. H., Verardo, D. J., and Dokken, D. J.: Land use, land-use change, and forestry: a special report of the Intergovernmental Panel on Climate Change, edited by: Watson, R. T., Noble, I. R., Bolin, B., Ravindranath, N. H., Verardo, David, J., and Dokken, D. J., Intergovernmental Panel on Climate Change, available at: http://www.grida.no/publications/other/ipcc_sr/, Cambridge Univ Press, Cambridge, UK, 377 pp., 2000.

Yamakura, T., Hagihara, A., Sukardjo, S., and Ogawa, H.: Aboveground biomass of tropical rain forest stands in Indonesian Borneo, Plant Ecol., 68, 71-82, 1986.

Zanne, A. E., Westoby, M., Falster, D. S., Ackerly, D. D., Loarie, S. R., Arnold, S. E. J., and Coomes, D. A.: Angiosperm wood structure: Global patterns in vessel anatomy and their relation to wood density and potential conductivity, Am. J. Bot., 97, 207215, doi:10.3732/ajb.0900178, 2010. 